\title{
Corporate Governance and the Cost of Debt: Evidence from Director Limited Liability and Indemnification Provisions
}

\author{
Michael Bradley ${ }^{\mathrm{a}}$ and Dong Chen ${ }^{\mathrm{b}, *}$ \\ ${ }^{a}$ Duke University, 1 Towerview Dr. Durham, NC, 27708, USA \\ ${ }^{\mathrm{b}}$ University of Baltimore, 1420 N Charles St, Baltimore, MD 21201, USA
}

\begin{abstract}
We find that firms that provide limited liability and indemnification for their directors enjoy higher credit ratings and lower yield spreads. We argue that such provisions insulate corporate directors from the discipline from potential litigation, and allow them to pursue their own interests by adopting low-risk, self-serving operating strategies, which coincidentally redound to the benefit of corporate bondholders. Our evidence further suggests that the reduction in the cost of debt may offset the costs of directorial shirking and suboptimal corporate policies occasioned by this insulation, which may explain why stockholders have little incentive to rescind these legal protections.
\end{abstract}

Keywords: limited liability provision, indemnification, corporate governance, cost of debt, risk taking, board of directors

JEL Classification: G30, G34, K22

\footnotetext{
${ }^{*}$ The authors thank the Duke Global Capital Markets Center for financial support. We also thank the analysts at Standard \& Poor's for providing insights into the ratings process and advice regarding our research design. In particular we would like to recognize Cliff Griep, Laurence Hazell, and Dan Konigsburg. We especially thank George Dallas, who has been an invaluable resource throughout this project. We also appreciate the helpful comments of an anonymous referee.
} 


\section{Introduction}

Much of the corporate governance literature centers on the alignment of the incentives of management and shareholders (Shleifer and Vishny, 1997; Becht et al., 2003). It is often assumed that if left to their own devices, managers/directors will pursue activities that benefit themselves at the expense of the firm's security holders. Although self-serving behavior may reduce the wealth of shareholders, it is not clear that all such behavior will also have an adverse effect on the firm's bondholders. For example, shirking would be harmful to both bondholders and shareholders. Taking on low-risk projects or engaging in conglomerate mergers, however, may benefit bondholders due to their concave payoff structure and the coinsurance effect associated with diversified acquisitions (Billett et al., 2004). Although there is debate in the literature regarding the risk-taking preference of managers/directors (Amihud and Lev, 1981; Holmstrom and Costa, 1986; Hirshleifer and Thakor, 1992; Adams et al., 2005), the evidence largely supports the proposition that managers/directors prefer conservative investment strategies that are suboptimal from shareholders' perspective, due to their concerns for the private benefits from control and their non-diversified firm-specific human capital (Bertrand and Mullainathan, 2003; John et al., 2008; Kempf et al., 2009; Laeven and Levine, 2009; Pathan, 2009).

Coincidentally, low-risk operating strategies may result in a reduction of the "agency costs of debt" (Jensen and Meckling, 1976; Myers, 1977), which ultimately would inure to shareholders' benefit. Indeed, it could well be the case that such reduction in the cost of debt equals or exceeds the costs of suboptimal corporate conduct and shirking by managers/directors, which would explain why some firms may tolerate managerial/directorial self-serving behaviors, which are expected if the firm is weakly governed. The rationale and effects of weak governance are 
similar to the rationale and effects of bond covenants in that shareholders restrict their own actions in exchange for a lower cost of debt. ${ }^{1}$

In this paper we study a particular type of governance mechanism that has received little attention in the finance literature, but may have strong incentive effects on corporate managers/directors. We study the effects of limited liability provisions and the indemnification of directors, henceforth "LLI", as specified in corporate charters, bylaws, or contracts written directly with directors. The importance of these provisions for directors is suggested by the annual survey by Tillinghast-Towers Perrin $(2004,2005,2006)$, that approximately $20 \%$ of the directors of American corporations have been the target of at least one legal action over the past 10 years. Though still not commonplace, recent experience illustrates that directors can suffer enormous losses of their personal wealth from stockholder litigation. ${ }^{2}$ As a result, we expect the protection from shareholder suits as afforded by LLI provisions may have a strong effect on directors' incentives to pursue their own interests. In contrast, the incentives provided by stock and stock options, which received far more attention in the literature, may be relatively small. Yermack (2004) reports that among the Fortune 500 companies, outside directors' wealth increases by only 11 cents per $\$ 1,000$ increase in firm value.

Our sample consists of the S\&P 1,500 firms from 2002 to 2007 that have publicly-traded, senior unsecured bonds outstanding. Our proxy for the strength of the LLI provisions at the firm level is an index - the "L-index" - which is the sum of three indicator variables: (1) the existence of liability limitation provisions in corporate charters or bylaws, (2) the indemnification of litigation expenses provided by corporate charters or bylaws, and (3) the existence of

\footnotetext{
${ }^{1}$ The difference is also obvious. While covenants are intentionally written into bond contracts to limit the actions of managers/directors, weak governance may reduce the cost of debt as a by-product of managers' low-risk operating strategy.

${ }^{2}$ The infamous cases of Enron and Worldcom illustrate the point: directors paid \$13 million out of their own pockets in the Enron case and $\$ 24.75$ million in the Worldcom suit.
} 
indemnification contracts with individual directors. The data for these provisions are taken from

RiskMetrics (formerly IRRC), which is the same database used by Gompers et al. (2003)

(hereafter "GIM") to construct their G-index.

Consistent with the argument made above, we show that managers/directors of firms with a

high L-index conduct low-risk corporate policies, which reduces the cost of debt significantly.

Shareholders benefit from such a reduction, and this benefit may offset the costs of suboptimal operating strategies and shirking by managers/directors. As a result, we find that firm

performance is not negatively affected by these provisions, which may explain why shareholders have little incentive to rescind them (Romano, 2006). ${ }^{3}$

In this paper we identify a channel through which LLI provisions affect firm value that differs dramatically from the existing literature. Previous work finds either a non-significant or weakly positive effect of these provisions on stock prices (Bhagat et al., 1987; Netter and Poulsen, 1989; Janjigian and Bolster, 1990; Romano, 1991; Brook and Rao, 1994; Heron and Lewellen, 1998). ${ }^{4}$ Focusing exclusively on shareholders, these authors assert that the empirical evidence suggests that the costs arising from the reduced pressure from judicial intervention caused by liability limitation and director indemnification are either equal to or are outweighed by the benefits of attracting and retaining talented directors. In contrast to our argument, they also conjecture that

\footnotetext{
${ }^{3}$ It should be noted that most of these protections were enacted by the states during the height of the hostile takeover wave in the late 1980s. The most celebrated case that prompted these actions is Smith vs. Van Gorkom, which ultimately led to Delaware's passage of Section 102(b)(7), which allows Delaware firms to opt into a provision that eliminates any financial liability of directors for breaches in the Duty of Care. Not surprisingly, a majority of Delaware firms opted into this provision (see, e.g., Bradley and Schipani, 1989). 45 other states followed Delaware's lead and passed similar legislation (Romano, 2006). The first state to enact a statute that allowed its incorporated firms to indemnify their directors for litigation expenses was New York in 1961. Today, 41 other states have similar statutes (Romano, 2006). An important question that we address in this paper is why such provisions persist if their major purpose is to insulate directors from the discipline of litigation and therefore allow them to pursue self-serving activities, as some have argued (e.g., Bishop, 1981). Historically, shareholders often oppose governance arrangement such as classified boards and majority voting. However, there have been very few instances in which shareholder activists have sought to rescind these provisions once they had been adopted (Romano, 2006).

${ }^{4}$ In contrast to our index approach, these papers typically test for only one of our LLI provisions (such as director liability limitation), or the LLI provisions separately. This is mainly due to their event-study methodology.
} 
LLI provisions encourage managers/directors, who would otherwise take overly conservative actions for fear of legal consequences, to engage in more risk-taking behaviors, which would be beneficial especially for firms with more growth opportunities (Bishop, 1981). It is important to note here that the event-study methodology employed in these papers prevents the authors from directly testing the implications of their theories. Consequently the explanations they offer are best understood as being suggestive. ${ }^{5}$ In contrast, we provide evidence that these provisions do not help to attract or retain talented directors and, contrary to the suggestions in these papers but consistent with our arguments above, managers/directors under the protection of these provisions take on lower, not higher, risky projects, especially when the firm has more growth opportunities.

Our work contributes to the small strand of literature on the incentives that potential litigation has on corporate directors, and the resulting effects on the value of the firm. Prior research has focused primarily on how stock and stock options, board composition, and reputational concerns provide the incentives for directors to fulfill their monitoring and advisory functions (e.g., see the review by Hermalin and Weisbach, 2003; Adams et al., 2010). However, very little research exists regarding how the concerns for the potential loss of personal wealth from legal actions affect the behaviors of corporate managers/directors. Among the current work on this topic, we are the first to include bondholders in the analysis and directly test the incentive and talentattraction effects of LLI provisions on managers/directors. Our results are inconsistent with the generally accepted explanation of the effects that these provisions have on shareholder wealth.

\footnotetext{
${ }^{5}$ The only paper that tests whether the director liability statute, the state statute that allows firms to include the provisions for director liability limitation in their charters, is related to the attraction of directors is Heron and Lewellen (1998), who find that firms reincorporated into a state with the statute for director liability limitation added more independent directors subsequently. But their evidence is not strong (average percent of independent directors increased from $53.6 \%$ to $56.2 \%$ in two years). Furthermore, this increase could also be driven by other contemporaneous factors that were unrelated to the reincorporation decisions, which are not being controlled for.
} 
We show that without considering bondholders' interests, the prevailing explanations for the existence and persistence of these provisions are misleading.

Our work also contributes to the general governance study. Closely related are studies by Klock et al. (2005), Ashbaugh-Skaife et al. (2006, “ACL” henceforth), and Chava et al. (2009b), who show that antitakeover strength of a firm as proxied by the G-index is associated with a lower cost of debt. The results they document, however, are subject to mixed interpretations due to the mixed meanings of the G-index as indicating antitakeover strength on one hand, and the weakness of shareholder rights on the other. In contrast, we study a governance mechanism and some components of the G-index that arguably are not strong antitakeover devices. ${ }^{6}$ We show that after netting out the effect of the L-index, the G-index is positively, not negatively associated with the cost of debt, in stark contrast to the studies above. Although not conclusive, our evidence implies that the antitakeover effect of the G-index may hurt bondholders, as takeovers may benefit them through the coinsurance effect (Qiu and Yu, 2009). ${ }^{7}$

Finally, to our knowledge, little prior work has analyzed the incentives for shareholders to change a given governance structure, especially in light of the agency costs of debt. ${ }^{8}$ Our results suggest an alternative channel through which governance matters for firm value: weak governance may benefit shareholders not because it aligns the incentives of managers/directors with stockholders, but because adopting low risk strategies decreases the agency costs of debt. Thus, our results demonstrate the importance of including bondholders in evaluating a governance structure.

\footnotetext{
${ }^{6}$ The three components of our L-index are also the components of the G-index, which is the sum of 24 managerial entrenchment/antitakeover indicators.

${ }^{7}$ This is particularly true if bondholders insist on event-risk covenants in their indenture agreements that preclude any expropriation of their wealth caused by a takeover.

${ }^{8}$ ACL also examine why firms choose to have weak corporate governance even if it hurts their credit ratings. Their explanation focuses on management, not shareholders. They argue that weak governance allows managers to extract greater compensation from the firm.
} 
The remainder of this paper is organized as follows. In the next section we discuss our primary empirical models and data. Section 3 presents our empirical results. Section 4 tests the talent attraction hypothesis suggested in the literature as an alternative explanation for our cost of debt results. Section 5 conducts several robustness checks. Finally, Section 6 concludes.

\section{Empirical Models and Data}

In this section, we discuss our primary model specifications for the relation between the cost of debt and our L-index. We also discuss the major variables, data sources and summary statistics. The detailed definitions for all the variables in the empirical analysis, as well as their type and sources are presented in the Appendix.

\subsection{Empirical Models and Variables}

We use two empirical methodologies to examine the relation between LLI provisions and the cost of debt. First, we test the differences between the credit ratings and bond spreads of firms without the LLI provisions and firms matched by similar characteristics that have at least one of these provisions. Second, we run regression models following Equation (1):

$$
\begin{aligned}
\text { Cost of Debt }= & f\left(\beta_{1} L-\text { index }+\beta_{2} G-\text { index }+\overline{\text { Control Variables }} \cdot \overline{\beta_{3}}+\overline{\text { Time Dummies }} \overline{\beta_{4}}\right. \\
& \left.+\overline{\text { Industry Dummies }} \overline{\beta_{5}}+\beta_{0}+\varepsilon\right),
\end{aligned}
$$

where $f$ is a general function of the arguments in parentheses. We employ two proxies for the cost of debt, the firm's credit rating as assigned by S\&P, and the yield spread for its publicly traded, senior unsecured bonds.

Following ACL, we group the S\&P long-term issuer credit ratings into 7 categories. We then estimate an ordered-probit model for this variable to take into account the nonlinear nature of ratings. Our primary coefficient of interest is $\beta_{1}$. Financial control variables are based on the existing literature (Klock et al., 2005; ACL; Qiu and Yu, 2009), including return on assets, a 
dummy indicating whether ROA is negative for both the current and previous years, firm size, book leverage ratio, interest coverage ratio, a dummy indicating whether the firm has subordinated debt, and equity volatility. We also control for operating cash flow since a higher cash flow implies a lower risk of financial default.

We control for an extensive list of governance variables based on the literature, including a dummy variable indicating whether the firm has a classified (staggered) board, CEO option and share holdings, board size and independence, the percentage of directors without any shareholdings, CEO power, the percentage of expert directors, institutional shareholdings, the number of institutional blockholders with at least $5 \%$ ownership, and earnings quality (Bhoraj and Sengupta, 2003; Larcker et al., 2004; Klock et al., 2005; ACL; Ortiz-Molina, 2006; Chen, 2010) ${ }^{9}$

Since our primary regressions are at the firm level, we calculate the yield spread as the weighted average spread of all outstanding senior unsecured bonds for a firm in a given year, where the weight is the ratio of the issue amount for the bond over the total amount of all the outstanding bonds in the sample for the firm in that year. The spread for an individual bond is defined as the difference between the yield-to-maturity (YTM) of the bond and the YTM of the U.S. Treasury Bond with the closest maturity. In the spread regressions, we also control for

\footnotetext{
${ }^{9}$ Ecker et al., (2006) calculate what they label as "e-loading," which is a measure of a firm's earnings quality. The measure is based on an accrual quality (AQ) measure, which is defined as the standard deviation of the residuals of a time-series regression of the firm's total current accruals on past, present, and future values of the firm's cash flows from operations, the firm's most recent change in revenues and the level of the firm's property, plant and equipment for each of the preceding five years. The intuition is that if there is a meaningful and sustaining relation between a firm's reported earnings and its cash flows, then one can conclude that the reported earnings are of high quality. They then augment the Fama-French three-factor model, and define the loadings on this additional AQ factor as the e-loading. As constructed, this measure represents the inverse of the earnings quality. In order to facilitate exposition and provide a more intuitive interpretation of this variable, we multiply the e-loading by -1 and denote the resulting variable Earnings Quality. Thus, in this reformulation, the higher this measure, the higher the quality of the firm's reported earnings and, presumably, the higher (better) the firm's credit rating and the lower its bond spread.
} 
several issue characteristics that proxy for the liquidity and systematic risk of a bond's return, including bond age, modified duration, and convexity (Klock et al., 2005; Qiu and Yu, 2009), in addition to the controls employed in the rating regressions. Similar to our treatment of spreads, we calculate a weighted average of these variables across the multiple issues of each firm in our sample. In our analysis of bond spreads, we also entertain a firm's credit rating to examine the extent to which our independent variables are perceived similarly or differently by the ratings agencies and bond traders. ${ }^{10}$ We consider the potential simultaneous determination of credit ratings and bond spreads in the robustness checks.

In all our empirical tests we include the Fama-French 48-industry and year dummy variables. Standard errors are adjusted for heteroscedasticity and clustered at the firm level (Petersen, 2009).

\subsection{Data and Sample}

We combine different databases in constructing the samples used in our empirical work. The bond prices and issue characteristics are taken from a proprietary database of S\&P, which covers all rated and publicly traded corporate bonds as of the end of March from 2002 to 2007 . The sample includes only senior unsecured seasoned bonds, which is a data limitation but is appropriate for our purposes, since unsecured bondholders may be more concerned about the governance structure of the firm as compared to secured bondholders. Furthermore, senior unsecured bonds are the lion's share of all outstanding bonds as suggested in the literature (Chava et al., 2009a).

\footnotetext{
${ }^{10}$ In personal interviews with several individuals who actually rate bonds at $\mathrm{S} \& \mathrm{P}$, we learned that they do not assign ratings based on a formulaic approach. Ratings are set by committees on a predetermined schedule or whenever there is a significant change in the situation of the firm. We were assured that most decisions were made on the basis of more qualitative, situation-specific issues regarding the firm's prospects for the future and the probability that the firm will be able to honor its commitments to bondholders, rather than just focusing on the firm's financials per se.
} 
The components of the L-index and the G-index are obtained from the RiskMetrics Governance Database, which covers the S\&P 1,500 firms biennially from 2000 to 2006 . We follow GIM and assume that the provisions are the same as those in the previous year, if that year's observations are not available.

Other data sources include COMPUSTAT, CRSP, EXECUCOMP, Thomson Reuters, RiskMetrics Director Database, and Thomson One Banker.

When merging different data sources we take care to ensure that other variables are available to investors before the date on which we collect data for bond spreads, in order to alleviate concerns about endogeneity. For example, year $t$ data for the yield spreads are matched with year $t-1$ data from COMPUSTAT.

We delete firms with dual-class stocks, since the special voting arrangement of these firms may imply a minimal role for other governance structures. We also delete firms whose board size is less than four, as this probably reflects data errors for our large firms in the sample. We also winsorize the major variables at the $1^{\text {st }}$ and $99^{\text {th }}$ percentiles to alleviate concerns for outliers. Our final sample for the cost of debt regressions contains 1,494 firm-year observations from 2002 to 2007, with 430 unique firms.

\subsection{Summary Statistics}

Table 1 presents the summary statistics and correlations for the variables in our primary analyses. Panel A lists the summary statistics of each of the variables. We also report the summary statistics for L-dummy, a dummy variable that equals one if the firm has any of the three LLI provisions, and zero otherwise. The data show that the median firm in the sample has one LLI provision, and $61 \%$ of the firms have at least one LLI provision. The yield spreads in our sample are slightly larger than those reported in Klock et al. (2005) based on a sample earlier 
than ours. The credit ratings of our firms are about the same as in Klock et al. (2005) and ACL. The data for the G-index largely match those reported in these papers.

Insert Table 1 about here

Panel B lists the change in the L-index and the G-index over the sample period. Since we assume that year $t+1$ data are the same as year $t$ data if the former are not available, and our year convention is based on the bond sample, we report the changes of these two variables over three time periods: from 2002 to 2003 , from 2003 to 2005 , and from 2005 to 2007 . We also only require that we have the data for these changes (i.e., data may be missing for other variables) to enlarge the sample size. As Panel B indicates, the L-index is remarkably stable over time. For example, between 2002 and 2003, only 27 of the 1,206 firms (2.2\%) changed their L-index. The percentage is even smaller for other time periods. ${ }^{11}$ Therefore, similar to the incidences of classified boards as documented in the literature (Bebchuk and Cohen, 2005; Masulis et al., 2007; Bates et al., 2008; Chen, 2010), it appears that most LLI provisions were also established prior to 1990, presumably at the height of hostile takeovers, and changed little afterwards. Consequently, similar to the arguments in these papers, endogeneity (reverse causality) is not a serious concern in this study. Nevertheless, we examine the potential endogeneity of our results, including the omitted variable bias in the robustness checks presented subsequently. We explore the potential reason for the stability of the L-index in Section 3. In contrast, the G-index is much more variable. For example, between 2003 and 2005, 24.7\% of the firms changed their Gindexes. The time-series stability of the L-index motivates our choice of ordered-probit and pooled OLS as the primary econometric models (Zhou, 2001).

\footnotetext{
${ }^{11}$ In undocumented analysis, we find that for the much longer period from 1990 to 2006 the stability of the L-index still holds: for the 589 firms that remain in the S\&P 1,500 index from 1990 to 2006, less than 4\% of them changed their L-indexes at any given year.
} 
Panel C reports the correlation matrix for the major variables of interest. The L-index is negatively correlated with bond spreads and positively correlated with bond ratings, which is consistent with our hypothesis that LLI provisions reduce the costs of debt. The correlation between the L-index and the G-index is 0.46 . Since the components of the L-index are also the components of the G-index, it may be better to control for a "Remaining G-index", an index comprised of the components in the G-index that are not in the L-index, for a clearer interpretation of the results. However, for ease of comparison with the existing literature, we still employ the G-index in our primary analysis. In undocumented robustness checks, we repeat all the analyses with this alternative index. The results remain qualitatively similar.

\section{Empirical Results}

Previously we argued that weak governance, as proxied by the number of LLI provisions, may permit corporate directors to adopt relatively low-risk corporate policies that decrease the agency costs of debt and thereby benefit the firm's stockholders. This benefit may equal or outweigh the costs from shirking and the suboptimal operating strategies. Consequently, these provisions may have a non-negative impact on firm performance. To test this hypothesis, we first examine the relation between the L-index and the cost of debt. We then test the proposition that managers/directors of firms with more LLI provisions adopt relative low-risk projects, and present evidence of shirking by the directors of these firms, as manifested by a lower quality of monitoring. Finally, we present evidence regarding the relation between the L-index and firm value. Our purpose here is to examine whether there is any credence to our proposition that shareholders have no incentive to rescind existing LLI provisions.

\subsection{LLI Provisions and the Cost of Debt}


We first test the differences between the credit ratings and bond spreads of firms without any LLI provisions and firms matched by similar characteristics that have at least one LLI provision. We construct our matched sample using two matching procedures: industry and firm size, and industry and credit rating. The second procedure is employed since a firm's credit rating may be considered as a summary statistic of the firm's financial condition. Panel A of Table 2 presents the t-tests results. ${ }^{12}$ Consistent with our expectations, bond spreads (credit ratings) of the firms with the LLI provisions are significantly lower (higher) than those of the firms without these provisions based on samples matched by industry and firm size, and the results for bond spreads hold when samples are matched by industry and credit rating. These results suggest that compared with the average spread of the firms without any LLI provisions, the average spread of the firms in the same industry and with similar sizes, and with at least one of these provisions is reduced by $14.2 \%$. These results are consistent with our prediction that firms with LLI provisions enjoy a lower cost of debt.

Next, we run regressions following specification (1). We first fit an ordered-probit model for credit ratings, controlling for financial and governance variables, as well as year and industry fixed effects. The results are presented as Model 1 in the Panel B of Table 2. As shown, the Lindex is strongly and positively associated with ratings. The coefficient on the L-index is 0.174 and is significant at the $1 \%$ level. Interestingly, the coefficient on the G-index is negative and weakly significant at the $10 \%$ level, rather than positive, as reported in ACL. ${ }^{13}$

Insert Table 2 about here

\footnotetext{
${ }^{12}$ Results using the Wilcoxon signed-rank tests are similar.

${ }^{13}$ We note that ACL do not control for operating cash flow and volatility, the two variables that we find to be strongly related to ratings as expected. Furthermore ACL do not entertain as many governance control variables as we do. Finally, their sample covers only one year, 2003. It should be noted that we are able to replicate their findings if we use the same control variables and sample year as they do.
} 
The coefficients on the financial variables all have their expected signs and are generally significant. CEO option holdings are positively related to ratings, which is inconsistent with the findings in Ortiz-Molina (2006), who document a positive relation between CEO options and bond spreads. We note the difference in the definition of these two option variables. We define CEO option holdings as the Black-Scholes value of CEO option awards as a fraction of CEO total compensation, while Ortiz-Molina (2006) defines his measure as the number of shares in unexercised options over the total shares outstanding. If we use this definition, then the coefficient on CEO option holdings is indeed negative and significant. This result is interesting but puzzling. We leave for future research an explanation of this conundrum.

Consistent with the findings reported in Ortiz-Molina (2006), CEO shareholdings are negatively related to credit ratings. The coefficients on the fraction of directors without any shares and the number of institutional blockholders are also negative and significant, consistent with the results reported by ACL. Our measures of earnings quality and board size are positively related to credit ratings. The latter relation is consistent with the results in Larcker et al. (2004).

To gauge the economic significance of the L-index on ratings, we run a probit regression in Model 2 of the Panel B in Table 2, where the dependent variable is a dummy variable which is equal to one if the firm's rating is investment-grade (better than S\&P's BB+ rating) and zero otherwise. For ease of interpretation, we also use the L-dummy and control for the Remaining Gindex (rather than the G-index) in the statistical model, and report the marginal effects. The marginal effect on the L-dummy suggests that adding one provision for a firm initially without any LLI provisions increases the probability that the firm receives an investment-grade rating by $3.8 \%$, which is economically significant for this single variable. 
Models 3 through 5 report the results of our spread regressions based on specification (1). Model 3 reports the results without controlling for ratings. Consistent with the rating regression results, the L-index is negative and strongly associated with bond spreads, while the G-index is positive. Since the L-index is a sub-index of the G-index, the marginal effect of adding one component to the L-index should be the sum of the coefficients for the L-index and the G-index, which is $-0.213 \%$. This implies a $12.3 \%$ decrease of the bond spread for the median firm in the sample, and is certainly economically significant. In contrast, adding one provision of the Gindex is associated with a $9.1 \%$ increase in the spread for the median firm. Consistent with our results with respect to credit ratings, $\mathrm{CEO}$ option holdings and earnings quality are negatively, while institutional blockholders are positively associated with bond spreads. ${ }^{14}$

In Model 4 we add the rating dummies to test whether rating agencies and bond traders view our independent variables similarly. If they do, the coefficients on those variables should lose significance after controlling for the rating dummies (Bhoraj and Sengupta, 2003). The results suggest that except for volatility and CEO option holdings, all other variables appear to be viewed differently by these two entities. In particular, the L-index continues to be negative and highly significant. This result implies that the effect of the LLI provisions on bondholders is not (fully) captured by a firm's credit rating. The same is true for a number of other independent variables. ${ }^{15}$ We focus on the specification in Model 3 in subsequent analysis.

Our results that the G-index is negatively related to ratings and positively related to spreads are in contrast with most of the existing literature (e.g., Klock et al., 2005; ACL; Chava et al.,

\footnotetext{
${ }^{14}$ The results with respect to CEO option holdings and earnings quality hold with a first-difference (change) regression model, which is presumably subject to less endogeneity concerns.

${ }^{15}$ In short, bond ratings are not sufficient statistics for explaining (predicting) bond spreads.
} 
2009b). ${ }^{16}$ We note here the importance of netting out the negative effect of the L-index in interpreting the G-index in Model 5, where we do not include the L-index as one of the explanatory variables. Other variables are the same as in Model 3. Interestingly, the G-index is no longer significant. This result suggests a different interpretation of the L-index as compared with other components of the G-index. We control for the G-index throughout this paper.

The results presented in Table 2 suggest that LLI provisions benefit bondholders. In the next two subsections we examine the relations between these provisions and the risk-taking behavior of managers/directors and the diligence with which directors discharge their monitoring function.

\subsection{LLI Provisions and Risk-Taking Behavior}

The extant literature suggests that the protection of personal wealth from stockholder suits motivates managers/directors to take the appropriate (value-maximizing) amount of risk, as otherwise they may be overly conservative for fear of potential litigation accompanied by the low payoff of the risky action. However, the immunization from litigation costs and damages may also enable managers/directors to pursue their personal interests by conducting low-risk investment policies at the expense of the firm's shareholders, due to their concerns for retaining their private benefits from control and their non-diversified firm-specific human capital. We test these competing hypotheses by examining four variables that we believe to be measures of risktaking behavior: $R \& D$ expenditures, capital expenditures, number of diversifying acquisitions and equity volatility. In the first three regressions we control for lagged Tobin's Q, ROA, firm size, book leverage, and cash flow. In the regression for the number of diversifying acquisitions we also include a dummy variable for whether the firm acquires another firm in a given year, to

\footnotetext{
${ }^{16} \mathrm{We}$ also use the entrenchment index (E-index) as in Bebchuk et al. (2009) in place of the G-index, and obtain similar results. Controlling for the L-index, the E-index is negative but not significant for credit ratings and positive and strongly significant for bond spreads. The L-index continues to be positive and significant for ratings, and negative and significant for spreads.
} 
account for the possibility that the results are driven by that firms with a higher L-index also conduct more acquisitions in general, which may mechanically imply more diversifying acquisitions. The control variables for the equity volatility regression follow Cheng (2008) and include ROA, one-year lagged ROA, two-year lagged ROA, firm size, leverage, board size, independent directors, CEO power, capital expenditures, firm age, and the number of business segments. The OLS regression results are reported in Table 3.

Insert Table 3 about here

The results show that LLI provisions are associated with lower, rather than higher, risk-taking behavior of managers/directors. The coefficients on capital expenditures and equity volatility are both negative. Moreover, firms with a higher L-index make more conglomerate mergers, which also reduces firm risk. In undocumented analysis, we find that the number of acquisitions is not significantly related to the L-index, suggesting that our result for conglomerate mergers is not driven by general empire building (Baumol, 1959), but rather by risk-reducing empire building (Treynor and Black, 1976). These low-risk activities should work to the benefit of bondholders, which is consistent with the results reported in Table 2. The evidence in Table 3 also suggests that the G-index is negatively associated with equity volatility, though the magnitude $(-0.004)$ is only one-third of that of L-index (-0.012). This evidence is consistent with the low-risk taking of managers of firms with a high G-index (John et al., 2008).

It is notable from Model 4 of Table 3 that CEO power is negative and significant, rather than positive as reported in Adams et al. (2005) and Cheng (2008). ${ }^{17}$ The signs of the other

\footnotetext{
${ }^{17}$ We note the difference between our definition of the CEO power and theirs: they define a CEO as being powerful if he/she is the founder of the firm, the sole insider on the board, and the chairman of the board. In undocumented analysis, we control for the dummies indicating whether the CEO is also the chairman, and whether he/she is the sole insider on the board. The results are similar, although these dummies are not significant. We do not have the data for whether the CEO is also the founder of the firm. But there should be little reason to suspect any bias on our L-index.
} 
independent variables are generally consistent with the findings reported in these papers, in particular board size, which is negative and consistent with Cheng (2008).

Though the results in Table 3 suggest that in general, the latitude provided by LLI provisions does not encourage risk-taking behavior on the part of managers/directors, it is possible that risktaking is most acute in growth firms, where such behavior is expected to be most beneficial for shareholders. We test this hypothesis by interacting a dummy variable indicating high growth opportunities with the L-index and the G-index, respectively. We use the lagged value of Tobin's Q to proxy for a firm's growth opportunities. ${ }^{18}$ If LLI provisions permit the managers and directors of growth firms to undertake high-risk projects, this interaction term should be positive for the regressions involving $R \& D$ and capital expenditures, and equity volatility, and negative for the number of diversifying acquisitions. However, the results in Table 4 do not support these predictions. The interaction term High lagged Q * L-index is positive for capital expenditures, but is insignificant. In contrast, the significant interaction terms have signs which are contrary to the predictions of the enhanced risk-taking hypothesis: the term is negative for R\&D and volatility, and positive for the number of diversifying acquisitions. The results reported in the table also indicate that none of the interaction terms involving the G-index is significant.

Insert Table 4 about here

To further test the relation between LLI provisions and the risk-taking behavior of corporate managers/directors, we examine the relation between the cost of debt and our L-index for firms that are in financial distress. It is expected that the conflict of interest between shareholders and bondholders intensifies with the deterioration of a firm's credit quality (Bodie and Taggart, 1978; John and John, 1993). Thus, if LLI provisions encourage directors to take more risk, it would hurt bondholders more the closer the firm is to default. We use two proxies for the firm's

\footnotetext{
${ }^{18}$ The results using the market-to-book ratio as a proxy for the growth opportunities are similar.
} 
closeness to default: a dummy variable indicating whether the credit rating is speculative (worse than or equal to S\&P's BB+ rating), and Altman's Z-score. A lower Z-score indicates that the firm is closer to default. We interact these indicators for a firm's credit quality with the L-index and the G-index and rerun our spread regressions. Models 1 and 2 in Table 5 report the results.

As indicated by the statistics, the results do not support the claim that LLI provisions increase the risk-taking behavior of managers/directors: the interaction term Speculative * L-index is negative and not significant, while Low Z-score * L-index is negative and significant at the $5 \%$ level, suggesting that when a firm is closer to default, LLI provisions benefit bondholders more, which is consistent with the low-risk taking, rather than the high-risk taking behavior of managers/directors. Interestingly, the interaction term Low Z-score * G-index is positive and weakly significant, which is consistent with the joint hypothesis that the G-index is a proxy for the antitakeover strength of the firm, and that takeovers are beneficial to bondholders, perhaps due to the coinsurance effect which is most acute for financially troubled firms. Surprisingly, the Low Z-score dummy is negative, rather than positive as expected. This is probably the result of multicollinearity: the interaction term Low Z-score * G-index and G-index are highly correlated; Low Z-score dummy and some of the financial controls including ROA, leverage ratio, and interest-coverage ratio are also highly correlated. ${ }^{19}$

Insert Table 5 about here

\subsection{LLI Provisions and Directorial Shirking}

\footnotetext{
${ }^{19}$ In undocumented analysis we find that the correlation between the Low Z-score dummy and bond spread is 0.27 , and the correlation between the interaction term Low Z-score * G-index and G-index is 0.97 , suggesting that the unexpected sign on Low Z-score dummy may be due to multicollinearity. We also run the spread regression without the interaction term Low Z-score * G-index, ROA, leverage, interest coverage ratio. Low Z-score dummy is positive and strongly significant at the $5 \%$ level, consistent with expectations. The interaction term Low Z-score * L-index is still negative, but no longer significant.
} 
The results in subsection 3.2 are consistent with the hypothesis that directors protected by LLI provisions have the incentives and ability to pursue their self interests and conduct low-risk corporate policies, which benefit corporate bondholders. However, self-serving behaviors that involve directorial malfeasance or shirking do not necessarily aid bondholders. If the major function of corporate directors is to monitor management, shirking may result in a lower monitoring quality, which would be harmful to all security holders. ${ }^{20}$ We test this hypothesis by examining two proxies for the monitoring quality of corporate directors: CEO turnoverperformance sensitivity (TPS) and pay-performance sensitivity (PPS). It is expected that if directors monitor more diligently, both TPS and PPS should be higher. The results of these tests are presented in Table 6.

\section{Insert Table 6 about here}

Model 1 reports the results of a probit regression on TPS. The control variables follow the literature (Weisbach, 1988; Denis et al., 1997; Huson et al., 2001; Dahya et al., 2002). We delete the observations if the firm was a takeover target in a given year, as the CEOs of these firms may experience some abnormal turnovers. The interaction term between the High L-index (High Gindex) and the stock return is not significant, where the High L-index (High G-index) is a dummy indicating whether the firm's L-index (G-index) is higher than the median value in the sample. These results suggest that neither index is related to CEO turnovers.

We follow Jensen and Murphy (1990) and run an OLS regression on the change in total CEO compensation ( $\triangle \mathrm{CEO}$ compensation) on the change in market capitalization $(\Delta \mathrm{SW})$, and interact the High L-index (High G-index) dummy with $\Delta \mathrm{SW}$ to test the effect of the L-index (G-index)

\footnotetext{
${ }^{20}$ A lower monitoring quality may also enable managers to pursue corporate strategies for their own benefits. As argued in this paper, such strategies may include taking low-risk corporate policies. Thus shirking by itself is not necessarily harmful to bondholders. However, here we are examining the consequences of shirking by directors in deciding to retain or dismiss a firm's CEO and setting her compensation. Shirking in this context may be harmful to the firm's bondholders.
} 
on PPS. We also control for the change in independent directors, board size, institutional shareholdings, firm size, equity volatility, ROA, and the market-to-book ratio. Following Coles et al. (2007), we delete the firm-year observations that experienced a CEO turnover in the current or previous year, and require that the CEO's tenure to be at least two years. This ensures that we do not include the change in CEO compensation for fractional years. Interestingly, the interaction term High L-index $* \Delta \mathrm{SW}$ is negative and strongly significant at the $1 \%$ level. Moving from a low L-index firm to a high L-index firm decreases the PPS from 0.003 to 0.001 . In contrast, moving from a low G-index firm to a high G-index firm doubles the PPS from 0.003 to 0.006 .

Though the results in Table 6 show that more LLI provisions are associated with less diligent directors (directorial shirking), it is not clear whether a lower PPS is bad for bondholders as it is for shareholders, since a lower PPS may suggest that the CEO compensation is more aligned with the claim structure of bondholders. ${ }^{21}$ We test this by controlling for PPS in the spread regression, where the PPS is defined as $\frac{\Delta C E O \text { compensation }}{\Delta S W}$. The results are shown in Model 3 of Table 5. Indeed, PPS is negative and strongly associated with bond spreads, suggesting that a lower PPS is also harmful for bondholders.

To further test the shirking hypothesis, we examine whether bondholders benefit less from a higher L-index if the agency costs of the firm are high. The hypothesis is that diligent directorial monitoring should be more valuable for firms with higher agency costs, and hence the lower monitoring quality associated with the LLI provisions would hurt security holders more for those firms, including bondholders. We use two proxies for a firm's agency costs: free cash flow (Jensen, 1986), and whether the firm has an institutional blockholder (Bertrand and

\footnotetext{
${ }^{21}$ Indeed, in unreported analysis, we find that the L-index (G-index) is associated with higher (lower) CEO cash compensation.
} 
Mullainathan, 2001). It is expected that firms with higher free cash flows and firms without an institutional blockholder incur higher agency costs. We follow Lehn and Poulsen (1989) to calculate the free cash flow, and interact a dummy indicating whether the free cash flow is above the sample median with the L-index (G-index) in the spread regression. Model 4 in Table 5 shows the results. Consistent with the shirking hypothesis, the interaction term High free cash flow * L-index is positive and weakly significant at the $10 \%$ level, which suggests that firms with higher agency costs benefit less from a higher L-index. In Model 5 we interact the dummy for whether the firm has an institutional blockholder with the L-index (G-index). The interaction term (No blockholder * L-index) is positive and strongly significant at the $1 \%$ level. In fact, the coefficients on this interaction term (0.688) and L-index (-0.499) indicate that if the firm does not have an institutional blockholder, a higher L-index hurts bondholders. It is also noteworthy that none of the interaction terms involving the G-index is significant.

\subsection{The Incentive of Shareholders to Rescind the LLI Provisions}

In this subsection we examine the incentives of shareholders to rescind LLI provisions. Since most of these provisions were established in the mid- to late 1980's during the heyday of hostile takeovers (Bradley et al., 1987), we focus on rescissions, or the lack thereof, rather than initiations of LLI provisions. Our previous results suggest that LLI provisions reduce the cost of debt, which presumably benefits shareholders. The costs of these provisions, however, are suboptimal, low-risk operating strategies and directorial shirking. The relative magnitudes of the benefit and costs of these provisions determine their net effect on firm value. We therefore examine how LLI provisions affect firm performance to gauge the incentive of shareholders to rescind these provisions. 
We first examine whether there is any evidence that the number of LLI provisions is positively associated with a firm's litigation risk, as an indication for whether firms implement these provisions optimally. An optimal adoption of these provisions implies a lack of incentives of shareholders to change them. We follow the existing literature and practitioners' advice in choosing the firm-level variables that may be related to litigation risk. It is expected that directors of larger firms, financially distressed firms, growth firms, and firms with more shareholders may benefit more from the LLI provisions, as these firms are more likely to be sued (Core, 1997; Gische, 2000). We use Altman's Z-score to proxy for the extent of a firm's financial distress. Model 1 in Table 7 presents the OLS regression results, with the L-index as the dependent variable. As expected, firm size and the number of shareholders are positively, and the Z-score is negatively related to the L-index. The coefficient on market to book is positive but not significant. Overall, the results support the claim that firms use LLI provisions rationally, in that firms with higher litigation risk also grant their directors more provisions. ${ }^{22}$

Insert Table 7 about here

We now examine how the L-index affects firm performance. We use Tobin's Q as a proxy for performance following the convention in the literature. Control variables include firm size, ROA, intangible assets, leverage, $R \& D$ and capital expenditures, firm age, number of business segments, and a dummy variable indicating whether the firm is in the S\&P 500 index (SP500). The costs of suboptimal operating strategies and directorial shirking on shareholders are well established in the literature. There is little empirical evidence on the benefit of a reduced cost of

\footnotetext{
${ }^{22}$ These results are best interpreted as the average effect of these litigation risk factors on the cross-sectional variation of the LLI provisions, since these factors fluctuate much more than the provisions. Our intent here is to examine that even though firms seem not have changed these provisions often once they were established in the 1980 s, the establishment and strength of them may be driven by the litigation risk. The results suggest that the crosssectional variations for the ranking of these litigation factors may be much smaller than their time-series fluctuations, hence even using a sample as recent as ours, the results still suggest that litigation risk is positively correlated with the L-index. But there is a caveat to interpreting these results: the regression coefficients are understood as cross-sectional correlations, rather than causal effects.
} 
debt on firm performance, however. ${ }^{23}$ We therefore first examine whether bond spreads (credit ratings) are negatively (positively) associated with Tobin's Q. To reduce the concerns of endogeneity, we adopt a first-difference (change) regression. In addition to the change in bond spreads and credit ratings, we also include changes of each of the control variables as mentioned above, except for firm age. The change of SP500 is not included in this regression due to the lack of variation of this variable within the sample period. Model 2 in Table 7 presents the results. Indeed, the change of bond spread (credit rating) is negatively (positively) associated with the change of Tobin's Q, suggesting that a reduced cost of debt is associated with an improved firm performance as expected.

In Model 3, we further examine this by testing whether the predicted reduction of the cost of debt due to our L-index is associated with higher performance, similar to the methodology in Core et al. (1999). We use the empirical model in Model 3 of Table 2 to calculate the predicted reduction of the cost of debt due to the L-index scaled by bond spread $(=0.370 * \mathrm{~L}-$ index/Spread). We use an OLS model, rather than a change regression, since the stability of the L-index implies that the variability of this predicted reduction of the cost of debt is mainly driven by its denominator. Therefore, a change regression on this variable is similar to Model 2, and is not meaningful. We also control for the G-index in the OLS model. The results are presented in Model 3. The predicted reduction of the cost of debt due to the L-index is indeed positively associated with Tobin's Q. Furthermore, consistent with GIM, the G-index is associated with lower firm performance.

The results in Models 2 and 3 are consistent with our expectation that a reduced cost of debt associated with LLI provisions benefits shareholders, which results in improved firm performance. However, this benefit needs to be balanced against the costs of these provisions as

\footnotetext{
${ }^{23}$ We thank an anonymous referee for pointing this out.
} 
documented earlier. Therefore, in Model 4 we examine the net effect of the L-index on firm performance. The results show that the L-index is positive but not significantly associated with firm performance, which suggest that the benefit of a lower debt financing cost may offset the costs of suboptimal operating strategies and directorial shirking induced by LLI provisions. ${ }^{24}$ Therefore, shareholders may have little incentive to alter these provisions. This is consistent with the remarkable stability of the L-index as we observed in Table 1.

The results in this section also call for a fresh look at the widely-studied G-index. Our evidence suggests that firms with a higher G-index have a higher PPS, which should benefit both shareholders and bondholders. We also provide weak evidence that the G-index is associated with lower firm risk. All these results suggest that bondholders should benefit from the provisions in the G-index. However, evidence presented in Table 2 shows the opposite effect. Furthermore, the relation between performance and the G-index is negative. These results are hard to reconcile with the interpretation of the G-index as proxying for weak shareholder rights. However, our evidence is compatible with the interpretation of the G-index as a measure of the antitakeover strength of the firm, and that takeovers are beneficial to bondholders (Billett et al., 2004; Qiu and Yu, 2009).

\section{Test of the "Talent Attraction" Hypothesis}

The literature discussed previously offers an alternative explanation for the beneficial effects of LLI provisions: they may help the firm to attract and retain talented directors. It could well be the case that this effect may drive the negative relation between the L-index and the cost of debt. In this section we examine this alternative hypothesis by testing whether our L-index is

\footnotetext{
${ }^{24} \mathrm{We}$ also use accounting measures of performance to further examine this result. As it turns out, L-index is positive and significant (at the $1 \%$ level) for ROA, and positive but insignificant for ROE.
} 
associated with a lower director turnover (departure) rate and/or a higher director addition rate, and whether the L-index is associated with higher ability of the firm's board members. ${ }^{25}$

Director turnover is defined as the percentage of the board members who experienced a turnover in a given year. Addition variables are defined similarly. In addition to the L-index and the G-index, other control variables included in the analysis follow Farrell and Whidbee (2000) and Yermack (2004). We run OLS regressions for both departure and addition models. The results are presented as Models 1 and 2 in Table 8.

Insert Table 8 about here

It is notable that this sample period favors finding the talent attraction effect of LLI provisions, since it is characterized by heightened litigation risk for corporate directors after the conspicuous corporate scandals as evidenced by Enron and Worldcom. Yet our results in Models 1 and 2 do not support this hypothesis: the L-index is not significant in either model. We note that the G-index is also insignificant in these regressions. These results suggest that firms with a high L-index or G-index are no different in attracting and retaining directors as other firms. ${ }^{26}$

Even though LLI provisions may not matter for the turnover or addition of directors, they may still help firms to recruit talented directors. We test this hypothesis by examining whether the Lindex is associated with the addition and retention of talented directors. We rely on two proxies for the ability (talent) of a board: the number of outside directorships held by the board members, and the percentage of the board members who are independent and are active executives from

\footnotetext{
${ }^{25}$ We also examine whether LLI provisions are related to the attraction and retention of talented independent directors, as well as active executives from other firms, since our sample period is characterized by an increased demand and a decreased supply of these types of directors (Chen, 2007; Linck et al., 2009). LLI provisions could be most valuable for firms during this time period in attracting and retaining these directors. However, the results are not significant, similar to the results with respect to the whole board.

${ }^{26}$ Since SOX and the new exchange listing standards impose higher independence standards on public firms, these results may be driven by the forced compliance by the regulations. We exclude all firms that were not in compliance with the regulations in 2002 by having less than a majority of independent directors on their boards. The results are similar.
} 
other firms (Fich, 2005; Chen, 2007). We run three models with the following dependent variables: (1) the average number of outside directorships for newly added directors; (2) the average number of outside directorships for the entire board; and (3) and the percentage of the board members who are active executives of other firms. The control variables are based on Booth and Deli (1996) for the first two regressions, and Boone et al. (2007) for the third regression. The results are presented in Models 3-5 of Table 8.

Again, the L-index is not significant in any of these models. Furthermore, the coefficient on the L-index is negative, rather than positive as predicted. In contrast, the G-index is positive and significant for the average directorships of the whole board, and the percent of independent active executives, suggesting that the G-index, rather than L-index, may help to attract more talented directors. ${ }^{27}$

Overall, the results in this section do not support the generally held view that LLI provisions help to attract and retain talented directors. ${ }^{28}$

\section{Robustness Checks}

In this section we perform a number of robustness checks to further substantiate our findings.

\subsection{D\&O Insurance and Omitted Variable Bias}

\footnotetext{
${ }^{27}$ We are aware of the possibility that the number of directorships may not proxy for the effectiveness of directors, even though the directors holding more directorships may be abler. Fich and Shivdasani (2006) document that if the majority of outside directors hold at least two outside directorships and hence are considered "busy", the board will not be effective. To further gauge the effect of the L-index (and the G-index) on the ability and effectiveness of the board, we rerun the regressions in Table 8 , and include a dummy variable indicating whether the directors of the firm are busy, which is defined as having at least one director holding at least two outside directorships in the regression of the average directorship of newly added directors, and the majority of the board members holding at least two outside directorships in the regression of the average directorship of the whole board. The results are similar. In particular, the G-index does not appear to attract "busy" directors.

${ }^{28} \mathrm{We}$ realize ability is inherently hard to measure. To further test the talent attraction hypothesis, we examine whether the LLI provisions benefit bondholders more when the firm's demand for abler directors is high. Our first variable to proxy for this demand is a principal factor from the standardized values of firm size, the number of business segments and leverage, following Coles et al. (2008). We also follow Brook and Rao (1994) and use a variable which indicates whether the firm is underperforming. We interact the dummies for higher advising demand based on these two variables with the L-index in the spread regressions. The coefficients on the two interaction terms are both insignificant, inconsistent with the talent attraction hypothesis.
} 
Since D\&O insurance also protects directors from potential litigation, it may incentivize directors similar to the LLI provisions. However, data on the type and amount of D\&O insurance held by the directors of public corporations are confidential and virtually impossible to obtain. ${ }^{29}$ This data deficiency may give rise to a potential omitted variable bias. We discuss the robustness of our empirical results in light of this bias in this subsection.

First, as argued in Bhagat et al. (1987, p726), D\&O insurance may not have as strong of an incentive effect as LLI provisions. The presence of $\mathrm{D} \& \mathrm{O}$ insurance may create a stronger incentive for shareholders to sue, and lawsuits often damage the reputations of managers/directors. This potential loss constrains, to a certain extent, managerial malfeasance. In contrast, director limited liability provisions preclude shareholders from suing the directors on the basis of a breach of duty of care. Moreover, indemnification does not induce stockholders to sue more frequently since there is no external reservoir from which to pay the damages. Boyer (2005) even argues that the purpose of D\&O insurance is not to protect corporate directors per se, but shareholders themselves, since directors are already protected by LLI provisions.

Second, Core (2000) and Chalmers et al. (2002) argue that the purchase of D\&O insurance represents opportunistic behavior on the part of managers and, as such, is often closely related to the quality of corporate governance. If this is the case, our extensive control of governance variables in the cost of debt regressions may significantly alleviate this omitted variable bias.

Finally, even if our governance controls do not fully capture the effects of D\&O insurance, the direction of the potential omitted variable bias depends on whether D\&O insurance and LLI provisions are substitutes or complements. Prior literature is not very helpful in answering this

\footnotetext{
${ }^{29}$ Linck et al. (2009) searched all proxy and financial statements of New York incorporated firms (New York requires firms to disclose information about D\&O insurance) and S\&P 500 firms in 1998, 2001, and 2004, but were only able to find information for D\&O insurance for 27 New York firms and 12 S\&P 500 firms. Our sample only has 73 New York incorporated firms. Therefore, it would be futile to search the D\&O insurance information for these firms and run regressions to check the robustness of our results.
} 
question. But since our sample period is characterized by dramatic developments in the $\mathrm{D} \& \mathrm{O}$ insurance market (Tillinghast-Towers Perrin $(2004,2005,2006)$ ), the stability of the LLI provisions imply that these provisions are substitutes, rather than complements to $\mathrm{D} \& \mathrm{O}$ insurance ${ }^{30}$ Hence, assuming D\&O insurance has similar incentive effects as LLI provisions, our regression results will be biased downward. This suggests that the significant results we document would be even stronger without the bias, and hence we only need to be careful in interpreting the insignificant results, in particular the results in our tests of the talent attraction hypothesis. Based on the results reported in Tables 8 , the results for the attraction of new directors (Model 2) may be mostly affected by this bias, since the signs of the coefficients are positive as expected, but statistically insignificant. However, even if adding $\mathrm{D} \& \mathrm{O}$ insurance data would render the results significant, the results in Model 3 of Table 8 suggest that the added directors for firms with a higher L-index are no abler than other firms (or, may even be less abler considering the bias), which is still inconsistent with the talent attraction hypothesis.

\subsection{Endogeneity}

The evidence in this paper is consistent with the observation that most LLI provisions were established before 1990 and changed little afterwards. This observation should alleviate the concerns for endogeneity significantly, especially the issue of reverse causality. Nevertheless, we employ change regressions in this subsection to further check the robustness of the results for the effect of LLI provisions on the cost of debt. The change regressions are immune to the bias induced by an omitted but time-invariant variable that is correlated with both the L-index and the cost of debt. The stability of the L-index as evidenced in Table 1, however, suggests that most of the observations on the change of the L-index ( $\Delta \mathrm{L}$-index) are zeros, which will dilute the power

\footnotetext{
${ }^{30}$ This is also consistent with the historical origin of the director liability statutes in the mid-1980s, which was a result of states responding to skyrocketing costs of D\&O insurance (Romano, 2006), due primarily to the ruling in Smith v. Van Gorkom. See discussion in footnote 3.
} 
of the tests dramatically. This issue is especially acute since during our sample period there were only 18 firms in our sample that changed their L-index. ${ }^{31}$ To reach a balance between sample size and the power of the tests, we match these 18 firms with firms that did not alter their Lindexes based on industry and similar characteristics. We then run change regressions for bond spreads based on samples that are composed of these 18 firms and their matched firms. In addition to $\Delta \mathrm{L}$-index, we also include the change of the $\mathrm{G}$-index ( $\Delta \mathrm{G}$-index) in the regressions, since these two changes may be highly correlated. We use four factors for the second matching variable (in addition to industry): firm size, leverage ratio, equity volatility, and credit rating. Leverage and equity volatility are used as the matching criteria because they are highly significant for the cost of debt based on the results in Table 2. The results of the change regressions are reported in Table $9 .^{32}$

Insert Table 9 about here

Regardless of the matching criteria, the results in this table show that an increase in the Lindex (G-index) is associated with a decrease (an increase) in the bond spread, consistent with our results reported in Table 2. Therefore, the results using the change regressions, though with small sample sizes, nonetheless are consistent with our earlier findings.

We further check the robustness of our results by rerunning the ratings and spread regressions at $2006,{ }^{33}$ and include only the firms that kept their L-indexes constant between 2002 and 2006. The results are also similar qualitatively.

\subsection{Simultaneous Determination of Credit Ratings and Bond Spreads}

\footnotetext{
31 The difference between this number and the number we reported in Panel B of Table 1 is due to the additional requirement here that we have the data available for the change of bond spreads.

${ }^{32}$ Model 3 only has 34 observations because for one firm that changed its L-index during the sample period there is not a matched firm based on industry and equity volatility.

${ }^{33}$ The regression is run at year 2006, instead of year 2007, because CEO option data has a large number of missing observations in 2007.
} 
In the spread regressions we have controlled for rating dummies. Credit ratings and bond spreads, however, are likely to be simultaneously determined by each other. We address this simultaneity in this subsection. We employ 2SLS models to address this issue.$^{34}$ Following Qiu and $\mathrm{Yu}$ (2009), we use the lagged credit rating as the instrumental variable for credit rating, and the three variables for issue characteristics: modified duration, convexity, and bond age as the instrumental variables for bond spread. Table 10 presents the results. ${ }^{35}$ Similar to the results in Table 2, L-index continues to be positive for credit ratings and negative for bond spreads.

Insert Table 10 about here

\subsection{Sample Selection Bias}

Since our cost of debt sample contains only publicly traded bonds, this raises concerns regarding a sample selection bias. We use Heckman's selection model to address this bias. We follow Ertugrul and Hegde (2008) and use three instruments for access to the public bond market: firm age, inclusion in the S\&P 500 index, and listing on the NYSE. Other control variables in the first stage include firm size, market-to-book ratio, ROA, equity volatility, leverage, and the Fama-French 48-industry and year dummies. We calculate the inverse Mills ratio and include it as an additional variable in the spread regression. The results are very similar to those obtained by OLS models. The coefficient on the L-index is -0.362 and the coefficient on the G-index is 0.187 , which are very close to the results we obtained in Model 3 of Table 2. Both are also highly significant at the $1 \%$ level.

\subsection{LLI Provisions and State Laws}

\footnotetext{
${ }^{34}$ Results using 3SLS models are similar.

${ }^{35}$ In undocumented analysis, we also show that the results in Table 2 remain if we use OLS models to run the regressions for credit ratings, or control for credit ratings (instead of the rating dummies) in the bond spreads regressions.
} 
Since firm-level provisions to limit the liability of directors or indemnify their litigation expenses are governed by state statutes, and state laws may cluster, our findings of the significant effects of LLI provisions on the cost of debt may suggest the significance of other state laws, which may be correlated with states' liability or indemnification statutes. ${ }^{36}$ We thus include controls for the relevant state laws as suggested by the literature to check the robustness of our findings (Romano, 2006; Mansi et al., 2009; Francis et al., 2010). We first consider the statutes to relax the fiduciary standards, as well as to cap the damages for liability litigation payable by directors. ${ }^{37}$ Presumably these statutes may have similar effects as the LLI provisions. However, controlling for these statutes does not alter any of our results. The two dummy variables that indicate incorporations in a state with a relaxed culpability standard or damage cap are associated with lower costs of debt but not significant. ${ }^{38}$ We next consider state payout restriction laws. Mansi et al. (2009) document that firms incorporated in states with more restrictive payout statutes enjoy a lower cost of debt. Including a variable indicating the minimum asset-to-liability ratio for payout, however, does not change any of our results. ${ }^{39}$ Finally, we consider state antitakeover laws. Francis et al. (2010) find that a larger number of these laws are associated with lower bond spreads. We create an index variable from the RiskMetrics database indicating the number of antitakeover laws for a firm incorporated in that state. ${ }^{40}$ None of our results are affected.

\subsection{L-index versus L-dummy}

\footnotetext{
${ }^{36}$ For example, most states follow Delaware's model for their statutes on director liability limitation. These statutes leave the decision to individual firms' shareholders to authorize the inclusion of the provisions to limit directors' liability. Therefore, firm-level LLI provisions are governed by the state statutes.

${ }^{37} \mathrm{We}$ are indebted to Roberta Romano for providing the coding of these state statutes.

${ }^{38}$ Perhaps this provides one rationale for why these statutes were historically far less popular than the director liability limitation and indemnification statutes. Only 6 states have the statutes for relaxed culpability standards, while only one has the damage cap statute (Romano, 2006).

${ }^{39}$ We thank John Wald for posting the data for this variable in his website.

${ }^{40}$ These include business combination laws, fair price laws, control share acquisition laws, constituency statutes, anti-greenmail (recapture of profits) laws, and cash-out laws.
} 
Throughout the paper we have used the L-index, the sum of the three indicators for the LLI provisions, as our proxy of the strength of the protection at the firm level to insulate directors from potential litigation. This index approach presumes that the three LLI provisions have similar incentive effects on corporate directors. GIM make a similar assumption in creating their 24-component G-index. However, this may not be the case empirically. In undocumented analysis, we find that the three provisions are positively and significantly correlated with each other. The three provisions are all positively related to ratings and negatively related to spreads individually. Although only the relation between director limited liability provisions and ratings is statistically significant, all three provisions are significant for spreads. We replace our L-index with the L-dummy and rerun all the regressions. The results are similar. The summary statistics presented in Table 1 also suggest that $31 \%$ of the firms do not have any LLI provisions. If we delete these firms from the sample, then the effect of the L-index on bond spreads is still negative, but no longer significant at the conventional levels. ${ }^{41}$ These results suggest that initiation of the LLI provisions may have a larger impact on directorial incentives and the cost of debt than addition to the existing LLI provisions.

\subsection{Additional Robustness Checks}

Finally, we conduct several robustness checks to further buttress our major findings. Ertugrul and Hegde (2008) show that the amount of stock and options granted to directors is negatively associated with the firm's bond spread. We calculate the annual stock and option awards by dividing the number of annual restricted stocks and options by the number of shares outstanding, and include these as additional controls in the spread regression. Including these independent variables dramatically reduces the sample size to 962 . Nevertheless, the results are qualitatively similar. However, director option grant is positively, instead of negatively associated with bond

\footnotetext{
${ }^{41}$ It is significant at the $15 \%$ level, however.
} 
spreads, in contrast with Ertugrul and Hegde (2008), while the amount of stock held by directors is not significantly related to spreads. The significance of director options, however, disappears when we run change regressions.

We exclude all finance and utility firms from the sample (one-digit SIC code "6" and twodigit SIC code "49") and rerun all the regressions. The results are similar. We also run the spread regressions with only the largest issue of each firm in a given year. The results are also qualitatively similar. Finally, we run the bond spread regressions using all of the bonds in our sample, rather than aggregating the different issues into a firm-level bond spread. We cluster the standard errors at the firm level. The results are also similar.

\section{Conclusion}

The basic thesis of this paper is that managerial self-serving behavior may not be detrimental to bondholders, as undisciplined managers may pursue risk-reducing activities that benefit bondholders. Since the reduced cost of debt inures to shareholders' benefit, it is also not clear whether weak governance is uniformly bad for shareholders.

We suggest that the provision of limited liability and indemnification (LLI) for corporate directors represents a weak form of corporate governance in the sense that these provisions allow managers/directors more latitude to pursue self-interested operating strategies. Because of their concerns for the private benefits from control, and their non-diversified human capital investment, managers/directors have incentives to undertake low-risk operating strategies that result in a lower cost of debt, which ultimately inures to the benefit of the firm's stockholders. We provide evidence of a strong negative relation between a firm's cost of debt and the provision of LLI for the firm's directors. This benefit to shareholders may offset the costs of suboptimal operating strategies and shirking by directors. Indeed, we provide evidence that firm 
performance is not significantly impacted by the provision of LLI, which may explain why shareholders have little incentive to rescind these provisions, even though most of them were implemented in the 1980s during the boom of the hostile takeovers. In most cases the provisions were designed to protect directors from stockholder suits alleging that they breached their fiduciary duty by rejecting a premium hostile takeover bid. Yet they persist today, perhaps because of the effects we have documented in this paper. We also provide evidence that is inconsistent with the widely held belief that the effect of these provisions is to attract and retain talented directors.

The results reported in this paper call for a new interpretation of the widely-studied G-index. Contrary to the existing literature, our results indicate that the G-index is negatively related to credit ratings and positively related to bond spreads. Our evidence suggests that it may be inappropriate to interpret the G-index as a proxy for weak shareholder rights. Rather our results are consistent with the view that the G-index measures the firm's antitakeover strength and that takeovers are beneficial to bondholders, presumably because of the coinsurance effect. 


\section{Appendix.}

\section{Variable Definition, Type and Source}

\begin{tabular}{|c|c|c|c|}
\hline Variable & Definitions and Calculations & Type $^{1}$ & Data Source \\
\hline \multicolumn{4}{|c|}{ Director limited liability and Indemnification } \\
\hline L-index & $\begin{array}{l}\text { Board liability limitation and indemnification (LLI) index, sum of the three firm-level } \\
\text { charter, bylaw, and contract provisions to limit the director liability to the extent allowed } \\
\text { by state laws, and/or to indemnify the directors for the expenses involved in a liability } \\
\text { lawsuits should the director follow due diligence (dirliab+dirind+dirindc). }\end{array}$ & $\mathrm{C}$ & RiskMetrics \\
\hline L-dummy & Equals one if the firm has any LLI provisions, and zero otherwise & $\mathrm{D}$ & RiskMetrics \\
\hline \multicolumn{4}{|l|}{ Cost of Debt } \\
\hline Rate & $\begin{array}{l}\text { Collapsed seven categories out of the } \mathrm{S} \& \mathrm{P} \text { long-term domestic issuer credit ratings } \\
\text { (data280). Specifically, Rate }=1 \text { if Rating }<=\mathrm{CCC}+\text {; Rate }=2 \text { if } \mathrm{CCC}+<\mathrm{Rating}<=\mathrm{B}+\text {; Rate }=3 \\
\text { if } \mathrm{B}+<\text { Rating }<=\mathrm{BB}+\text {; Rate }=4 \text { if } \mathrm{BB}+<\text { Rating }<=\mathrm{BBB}+\text {; Rate }=5 \text { if } \mathrm{BBB}+<\text { Rating }<=\mathrm{A}+\text {; } \\
\text { Rate }=6 \text { if } \mathrm{A}+<\text { Rating }<=\mathrm{AA}+\text {; Rate }=7 \text { if Rating }>\mathrm{AA}+\text {. }\end{array}$ & $\mathrm{C}$ & COMPUSTAT \\
\hline Spread & $\begin{array}{l}\text { Weighted average spread of all the senior unsecured bonds of the firm, with the weight } \\
\text { being the issue size of the bond as a percentage of the total aggregate issue sizes of all the } \\
\text { outstanding bonds in the sample of the issuing firm in a given year. The spread for an } \\
\text { individual bond is defined as the difference between the yield-to-maturity (YTM) of the } \\
\text { bond and the YTM of the Treasury Bond matched by the closest maturity. }\end{array}$ & $\mathrm{C}$ & S\&P Snapshot \\
\hline \multicolumn{4}{|l|}{ Issue Characteristics } \\
\hline Duration & $\begin{array}{l}\text { Weighted average modified duration of all the senior unsecured bonds of the firm, with the } \\
\text { weight being the issue size of the bond as a percentage of the total aggregate issue sizes of } \\
\text { all the bonds in the sample of the issuing firm in a given year }\end{array}$ & $\mathrm{C}$ & S\&P Snapshot \\
\hline Convexity & $\begin{array}{l}\text { Weighted average convexity of all the senior unsecured bonds of the firm, with the weight } \\
\text { being the issue size of the bond as a percentage of the total aggregate issue sizes of all the } \\
\text { bonds in the sample of the issuing firm in a given year }\end{array}$ & $\mathrm{C}$ & S\&P Snapshot \\
\hline Bond_age & $\begin{array}{l}\text { Weighted average age of all the senior unsecured bonds of the firm, with the weight being } \\
\text { the issue size of the bond as a percentage of the total aggregate issue sizes of all the bonds } \\
\text { in the sample of the issuing firm in a given year }\end{array}$ & $\mathrm{C}$ & S\&P Snapshot \\
\hline \multicolumn{4}{|l|}{ Financial Variables } \\
\hline Operating cash flow & Operating cash flow $(=($ data13-(data16-(data35-lagdata35) $)) /$ data6) & $\mathrm{C}$ & COMPUSTAT \\
\hline ROA & Return on asset (=data18/data6) & $\mathrm{C}$ & COMPUSTAT \\
\hline ROA at $\mathrm{t}-1$ & Lagged value of return on asset & $\mathrm{C}$ & COMPUSTAT \\
\hline
\end{tabular}

\footnotetext{
${ }^{1} \mathrm{C}$ denotes non-binary variable; $\mathrm{D}$ denotes binary variable.
} 


\begin{tabular}{|c|c|c|c|}
\hline ROA at $\mathrm{t}-2$ & Two-year lagged value of return on asset & $\mathrm{C}$ & COMPUSTAT \\
\hline Loss & Equals one if ROA is negative in current and previous fiscal year, and zero otherwise & $\mathrm{D}$ & COMPUSTAT \\
\hline Size & Firm size, $\log$ of total assets $(\log ($ data6 $))$ & $\mathrm{C}$ & COMPUSTAT \\
\hline Leverage & Book leverage $(=($ data $9+$ data34 $) /$ data6 $)$ & $\mathrm{C}$ & COMPUSTAT \\
\hline Intcov & Interest coverage ( $=$ data $13 /($ data 15 or data 339 if data $15=0$ or data 15 is not available $)$ ) & $\mathrm{C}$ & COMPUSTAT \\
\hline Subord & Equals one if the firm has subordinated debt, and zero otherwise (data80) & $\mathrm{D}$ & COMPUSTAT \\
\hline Return & The annual dividend reinvested total return to shareholders (trs1yr) & $\mathrm{C}$ & EXECUCOMP \\
\hline Return at $\mathrm{t}-1$ & The one-year lagged return & $\mathrm{C}$ & EXECUCOMP \\
\hline Return at $\mathrm{t}-2$ & The two-year lagged return & $\mathrm{C}$ & EXECUCOMP \\
\hline$\Delta \mathrm{SW}$ & The change of market capitalization over the previous year ( $\Delta$ data199*data 25$)$ & $\mathrm{C}$ & COMPUSTAT \\
\hline Acquirer & Equals one if the firm is an acquirer in a given year, and zero otherwise & $\mathrm{D}$ & Thomson One Banker \\
\hline $\mathrm{Mb}$ & Market-to-book ratio ((data6-data60+data199*data25)/data6) & $\mathrm{C}$ & COMPUSTAT \\
\hline Q & Tobin's Q ((data6-data60-data74+data199*data25)/data6) & $\mathrm{C}$ & COMPUSTAT \\
\hline Z-score & $\begin{array}{l}\text { Altman's Z-score, composite score indicating the distance to bankruptcy, defined as } \\
(3.3 *(\text { data } 15+\text { data } 16+\text { data } 18+\text { data } 49) / \text { data } 6+1.0 * \text { data } 12 / \text { data } 6+1.4 * \text { data36/data6 }+ \\
1.2 *(\text { data4-data5 }) / \text { data } 6+0.6 * \text { data } 199 * \text { data } 25 /(\text { data9 }+ \text { data34 }))\end{array}$ & $\mathrm{C}$ & COMPUSTAT \\
\hline Cashflow & $\begin{array}{l}\text { Sum of income before extraordinary items and depreciation over net PPE at the beginning } \\
\text { of the year ((data18+data14)/lagged data8) }\end{array}$ & $\mathrm{C}$ & COMPUSTAT \\
\hline Intangible & Intangible assets as a percentage of total assets (1-data8/data6) & $\mathrm{C}$ & COMPUSTAT \\
\hline \multicolumn{4}{|c|}{ Governance Variables } \\
\hline G-index & $\begin{array}{l}\text { Sum of } 24 \text { antitakeover/weak shareholder rights indicators from Gompers, Ishii and } \\
\text { Metrick (2003) }\end{array}$ & $\mathrm{C}$ & RiskMetrics \\
\hline Cboard & Equals one if the firm has classified board, and zero otherwise & $\mathrm{D}$ & RiskMetrics \\
\hline CEO compensation & CEO total compensation, TDC1/100 & $\mathrm{C}$ & EXECUCOMP \\
\hline CEO_option & $\begin{array}{l}\text { Black-Scholes value of CEO unexercised options as a percentage of CEO total } \\
\text { compensation }\end{array}$ & $\mathrm{C}$ & EXECUCOMP \\
\hline CEO_share & CEO share holding as a percentage of total shares outstanding, excluding options & $\mathrm{C}$ & EXECUCOMP \\
\hline Per_dir_noshare & Percentage of directors with no shareholdings & $\mathrm{C}$ & RiskMetrics \\
\hline Per_ind & Percentage of independent directors to total board size & $\mathrm{C}$ & RiskMetrics \\
\hline Board_size & Number of board members & $\mathrm{C}$ & RiskMetrics \\
\hline CEO_power & $\begin{array}{l}\text { Composite score representing the power of the CEO, where a firm receives one point if the } \\
\text { CEO is the chairman of the board, and one point for each major committee (compensation, } \\
\text { nomination, audit) that the CEO sits on. }\end{array}$ & $\mathrm{C}$ & RiskMetrics \\
\hline Expert director & Percentage of directors sitting on at least one other corporate boards & $\mathrm{C}$ & RiskMetrics \\
\hline
\end{tabular}




\begin{tabular}{|c|c|c|c|}
\hline Per_inst & Percentage of institutional shareholdings & $\mathrm{C}$ & Thomson Reuters \\
\hline Blockholder & Number of institutional block holders with at least $5 \%$ ownership & $\mathrm{C}$ & Thomson Reuters \\
\hline Earnings quality & $\begin{array}{l}\text { The negative of the loadings on the accrual quality (AQ) factor as augmented from the } \\
\text { Fama-French three-factor model, where AQ is defined as the standard deviation of the } \\
\text { residuals from the regressions of the change in working capital on past, current, and future } \\
\text { cash flow from operations (Ecker, Francis, Kim, Olsson, and Schipper (2006)). }\end{array}$ & $\mathrm{C}$ & $\begin{array}{l}\text { Frank Ecker of Duke } \\
\text { University }\end{array}$ \\
\hline Dir_share (Idir_share) & The aggregate percentage shareholdings of all (independent) directors & $\mathrm{C}$ & RiskMetrics \\
\hline Interlock & Dummy for whether the firm has any director interlocked with any other firm's directors & $\mathrm{D}$ & RiskMetrics \\
\hline Blk_idir & Dummy for whether the firm has any independent director with at least $5 \%$ ownership & $\mathrm{D}$ & RiskMetrics \\
\hline PPS & $\begin{array}{l}\text { Pay-performance sensitivity of CEO compensation, defined as the change of CEO } \\
\text { compensation over the change of the market capitalization. }\end{array}$ & $\mathrm{C}$ & COMPUSTAT/EXECUCOMP \\
\hline \multicolumn{4}{|c|}{ Turnover/Addition Variables } \\
\hline Dpt_dir & Departing directors as a fraction of board size in a given year & $\mathrm{C}$ & RiskMetrics \\
\hline Add_dir & Newly added directors as a fraction of board size in a given year & $\mathrm{C}$ & RiskMetrics \\
\hline CEO turnover & Equals one if the incumbent CEO is no longer the CEO next year, and zero otherwise & $\mathrm{D}$ & RiskMetrics \\
\hline \multicolumn{4}{|l|}{ Ability Variables } \\
\hline Dirship & The average number of outside directorships of all directors & $\mathrm{C}$ & RiskMetrics \\
\hline Add_dirship & The average number of outside directorships of all newly added directors & $\mathrm{C}$ & RiskMetrics \\
\hline Per_ie & $\begin{array}{l}\text { The number of independent directors who are active executives of other firms as a } \\
\text { percentage of total board size }\end{array}$ & $\mathrm{C}$ & RiskMetrics \\
\hline \multicolumn{4}{|l|}{ Risk-Taking Variable } \\
\hline R\&D & R\&D expenses as a percentage of firm assets (data46/data6), missing value coded as zero & $\mathrm{C}$ & COMPUSTAT \\
\hline Capexp & $\begin{array}{l}\text { Capital expenditure as a percentage of firm assets (data128/data6), missing value coded as } \\
\text { zero }\end{array}$ & $\mathrm{C}$ & COMPUSTAT \\
\hline Numdaqr & $\begin{array}{l}\text { Number of diversifying acquisitions the firm made in a given year. A firm made a } \\
\text { diversifying acquisition if the firm acquires another firm not in the same industry according } \\
\text { to the Fama-French } 48 \text { industries. }\end{array}$ & $\mathrm{C}$ & Thomson One Banker \\
\hline Volatility & Standard deviation of the monthly stock returns over the past 60 months & $\mathrm{C}$ & EXECUCOMP \\
\hline \multicolumn{4}{|c|}{ Other CEO/Director Characteristics } \\
\hline Dir_age & Average age of all directors & $\mathrm{C}$ & RiskMetrics \\
\hline CEO_age & CEO age & $\mathrm{C}$ & RiskMetrics \\
\hline Dir_tenure & The average tenure of directors in years & $\mathrm{C}$ & RiskMetrics \\
\hline CEO_tenure & The tenure for CEO in years & $\mathrm{C}$ & RiskMetrics \\
\hline
\end{tabular}


CEO out

Num_oe

Per_noe

Other Firm Characteristics

Firm_age

Segment

M\&A at t-1

Shareholder

SP500
Equals one if the CEO's tenure is less than the average tenure of directors, indicating that the CEO that appointed the average director was no longer with the firm

The number of outside directors (independent plus grey directors) who are active

executives of other firms

The percentage of outside directors (independent plus grey directors) who are not active executives of other firms to board size

The number of years since the firm was listed in CRSP

The number of business segments of the firm

Equals one if the firm has undergone any M\&A transactions in the previous year, and zero otherwise

The number of shareholders (data100/1000) in millions

Equals one if the firm is included in the S\&P 500 index, and zero otherwise
$\mathrm{D}$

RiskMetrics

$\mathrm{C}$

RiskMetrics

RiskMetrics

C CRSP

C COMPUSTAT/SEGMENTS

D Thomson One Banker

C COMPUSTAT

D COMPUSTAT 


\section{References}

Adams, R., Almeida, H., Ferreira, D., 2005. Powerful CEOs and their impact on corporate performance. Review of Financial Studies 18, 1403-1432

Adams, R., Hermalin, B., Weisbach, M., 2010. The role of boards of directors in corporate governance: a conceptual framework and survey. Journal of Economic Literature, forthcoming

Amihud, Y., Lev B., 1981. Risk reduction as a managerial motive for conglomerate mergers. Bell Journal of

Economics 12, 605-617

Ashbaugh-Skaife, H., Collins, D., LaFond, R., 2006. The effects of corporate governance on firms' credit ratings.

Journal of Accounting and Economics 42, 203-243.

Bates, T.W., Becher, D.A., Lemmon, M.L., 2008. Board classification and managerial entrenchment: evidence from the market for corporate control. Journal of Financial Economics 87, 656-677

Baumol, W., 1959. Business Behavior, Value, and Growth. New York: Macmillan.

Becht, M., Bolton, P., Roell, A., 2003. Corporate governance and control. In: Constantinides, G., Harris M., Stulz, R. (Ed.), The Handbook of Economics of Finance.

Bebchuk, L., Cohen, A., 2005. The costs of entrenched boards. Journal of Financial Economics 78, 409-433

Bebchuk, L., Cohen, A., Farrell, A., 2009. What matters in corporate governance? Review of Financial Studies 22, 783-827

Bertrand, M., Mullainathan, S., 2001. Are CEOs rewarded for luck? The ones without principals are. Quarterly Journal of Economics, 901-932.

Bertrand, M., Mullainathan, S., 2003. Enjoying the quiet life? corporate governance and managerial preferences. Journal of Political Economy 111, 1043-1075

Bhagat, S., Brickley, J., Coles, J., 1987. Managerial indemnification and liability insurance: the effect on

shareholder wealth. Journal of Risk and Insurance 54, 721-736.

Bhojraj, S., Sengupta, P. 2003. Effects of corporate governance on bond ratings and yields: The role of institutional investors and outside directors. Journal of Business 76, 455-476.

Bishop, J., 1981. Law of corporate officers and directors: indemnification and insurance. Deerfield, Ill.: CBC Clark Boardman Callaghan.

Billett, M., King, T., Mauer, D., 2004. Bondholder wealth effects in mergers and acquisitions: new evidence from the 1980s and 1990s. Journal of Finance 59, 107-135.

Bodie, Z., Taggart, R.A., 1978. Future investment opportunities and value of call provision on a bond. Journal of Finance 33, 1187-1200.

Boone, A., Field, L., Karpoff, J., Raheja, C., 2007. The determinants of corporate board size and composition: an empirical analysis. Journal of Financial Economics 85, 66-101.

Booth, J., Deli, D., 1996. Factors affecting the number of outside directorships held by CEOs. Journal of Financial

Economics 40, 81-104.

Boyer, M., 2005. Directors' and officers' insurance and shareholder protection. Working paper. HEC - Montreal. Bradley, M., Desai, A., Kim, H., 1988. Synergistic gains from corporate acquisitions and their division between target and acquiring firms. Journal of Financial Economics 21, 3-40.

Bradley, M., Schipani, C., 1989. The relevance of duty of care standard in corporate governance. Iowa Law Review 75, 1-74.

Brook, Y., Rao, R., 1994. Shareholder wealth effects of directors' liability limitation provisions. Journal of Financial and Quantitative Analysis 29, 481-497.

Chalmers, J., Dann, L., Harford, J., 2002. Managerial opportunism? evidence from directors' and officers' insurance purchases. Journal of Finance 57, 609-636.

Chava, S., Kumar, P., Warga, A., 2009a. Managerial moral hazard and bond covenants. Review of Financial Studies forthcoming

Chava, S., Livdan, D., Purnanandam, A., 2009b. Do shareholder rights affect the cost of bank loans? Review of

Financial Studies 22, 2973-3004.

Chen, D., 2007. The monitoring and advisory functions of corporate boards: theory and evidence. Working paper.

University of Baltimore.

Chen, D., 2010. Classified boards, the cost of debt, and firm performance. Working paper. University of Baltimore. Cheng, S., 2008. Board size and the variability of corporate performance. Journal of Financial Economics 87, 157176. 
Coles, J., Daniel, N., Naveen, L., 2007. Co-opted boards: costs, benefits, causes, and consequences. Working paper. Arizona State University.

Coles, J., Daniel, N., Naveen, L., 2008. Boards: does one size fit all? Journal of Financial Economics 87, 329-356.

Core, J.E., 1997. On the corporate demand for directors' and officers' insurance. Journal of Risk and Insurance 64, 63-87.

Core, J.E., Holthausen, R.W., Larcker, D.F., 1999. Corporate governance, chief executive officer compensation, and firm performance. Journal of Financial Economics 51, 371-406.

Core, J.E., 2000. The directors' and officers' insurance premium: an outside assessment of the quality of corporate governance. Journal of Law, Economics, and Organization 16, 449-477.

Dahya, J., McConnell, J.J., Travlos, N.G., 2002. The Cadbury committee, corporate performance, and top management turnover. Journal of Finance 57, 461-483.

Denis, D.J., Denis, D.K., Sarin, A., 1997. Ownership structure and top executive turnover. Journal of Financial

Economics 45, 193-221.

Ecker, F., Francis, J., Kim, I., Olsson, P., Schipper, K., 2006. A returns-based representation of earnings quality. The Accounting Review 81, 749-780.

Ertugrul, M., Hegde, S., 2008. Board compensation practices and agency costs of debt, Journal of Corporate Finance $14,512-531$.

Farrell, K., Whidbee, D., 2000. The consequences of forced CEO succession for outside directors. Journal of Business 73, 597-627.

Fich, E., 2005. Are some outside directors better than others? evidence from director appointments by fortune 1000 firms. Journal of Business 78, 1943-1971.

Fich, E., Shivdasani, A., 2006. Are busy boards effective monitors? Journal of Finance 61, 689-724.

Francis, B., Iftekhar, H., Kose, J., Maya, W., 2010. The effect of state antitakeover laws on the firm's bondholders. Journal of Financial Economics 96, 127-154.

Gische, D., 2000. Directors and officers liability insurance, available online at

http://library.findlaw.com/2000/Jan/1/241472.html

Gompers, P., Ishii, J., Metrick, A., 2003. Corporate governance and equity prices. Quarterly Journal of Economics $118,107-115$.

Hermalin, B., Weisbach, M., 2003. Boards of directors as an endogenously determined institution, a survey of the economic literature, FRBNY Economic Policy Review, April, 7-26.

Heron, R., Lewellen, W., 1998. An empirical analysis of reincorporation decision. Journal of Financial and Quantitative Analysis 33, 549-568.

Hirshleifer, D., Thakor, A.V., 1992. Managerial conservatism, project choice, and debt. Review of Financial Studies $5,437-470$.

Holmstrom, B., Costa, J.R.I., 1986. Managerial incentives and capital management. Quarterly Journal of Economics 101, 835-860.

Huson, M.R., Parrino, R., Starks, L.T., 2001. Internal monitoring mechanisms and CEO turnover: A long-term perspective. Journal of Finance 56, 2265-2297.

Janjigian, V., Bolster, P., 1990. The elimination of director liability and stockholder returns: an empirical investigation. Journal of Financial Research 13, 53-60.

Jensen, M., 1986. Agency costs of free cash flow, corporate finance, and takeovers. American Economic Review, 76, 323-329.

Jensen, M., Meckling, W., 1976. Theory of the firm: managerial behavior, agency costs, and ownership structure. Journal of Financial Economics 3, 305-360.

Jensen, M., Murphy, K., 1990. Performance pay and top-management incentives, Journal of Political Economy 98, 225-264.

John, K., Litov, L., Yeung, B., 2008. Corporate governance and risk-taking. Journal of Finance 63, 1679-1728.

John, T.A., John, K., 1993. Top-management compensation and capital structure. Journal of Finance 48, 949-974.

Kempf, A., Ruenzi, S., Thiele, T., 2009. Employment risk, compensation incentives, and managerial risk taking: evidence from the mutual fund industry. Journal of Financial Economics 92, 92-108.

Klock, M., Mansi, S., Maxwell, W., 2005. Does corporate governance matter to bondholders? Journal of Financial and Quantitative Analysis 40, 693-719.

Laeven, L., Levine, R., 2009. Bank governance, regulation, and risk taking. Journal of Financial Economics 93, 259275.

Larcker, D., Richardson, S., Tuna, I., 2004. Does corporate governance really matter? Working paper. University of Pennsylvania. 
Lehn, K., Poulsen, A., 1989, Free cash flow and stockholder gains in going private transactions, Journal of Finance 44, 771-787.

Linck, J., Netter, J., Yang, T., 2009. The effects and unintended consequences of the Sarbanes-Oxley Act on the supply and demand for directors. Review of Financial Studies 22, 3287-3328.

Mansi, S., Maxwell, W., Wald J., 2009. Credit protection laws and the cost of debt. Journal of Law and Economics $52,701-726$.

Masulis, R.W., Wang, C., Xie, F., 2007. Corporate governance and acquirer returns. Journal of Finance 62, 18511889.

Myers, S.,1977. Determinants of corporate borrowing. Journal of Financial Economics 5, 147-175.

Netter, J., Poulsen, A., 1989. State corporation laws and shareholders: the rent experience, Financial Management $18,29-40$.

Ortiz-Molina, H., 2006. Top management incentives and the pricing of corporate public debt. Journal of Financial and Quantitative Analysis 41, 317-340.

Pathan, S., 2009. Strong boards, CEO power and bank risk-taking. Journal of Banking \& Finance 33, 1340-1350.

Petersen, M., 2009. Estimating standard errors in finance panel data sets: comparing approaches. Review of

Financial Studies 22, 435-480.

Qiu, J., Yu, F., 2009. The market for corporate control and the cost of debt. Journal of Financial Economics 93, 505524.

Romano, R., 1991. The shareholder suit: litigation without foundation? Journal of Law, Economics, and

Organization 7, 55-87.

Romano, R., 2006. The states as a laboratory: legal innovation and state competition for corporate charters. Yale Journal on Regulation 23, 209-247.

Shleifer, A., Vishny, R., 1997. A survey of corporate governance. Journal of Finance 52, 737-783.

Tillinghast - Towers Perrin, 2004, 2005, 2006. Directors and officers liability survey.

Treynor, J., Black, F., 1976. Corporate investment decisions. In: Myers S. (Ed.), Modern Developments in Financial Management. New York, Praeger, pp. 310-327.

Weisbach, M.S., 1988. Outside directors and CEO turnover. Journal of Financial Economics, 431-460.

Yermack, D., 2004. Remuneration, retention, and reputation incentives for outside directors, Journal of Finance 59, 2281-2308.

Zhou, X., 2001. Understanding the determinants of managerial ownership and the link between ownership and performance: comment. Journal of Financial Economics 62, 559-571. 


\section{Table 1. Summary Statistics and Correlations}

This table reports the summary statistics and correlations of the major variables used in the empirical analysis. Panel A reports the summary statistics. Panel B reports the changes of the L-index and the G-index over the sample period. Panel C lists the correlation matrix for the major variables. Definitions for all the variables are in the Appendix, except that Size is the total assets of the firm, without taking logs. Spread, Duration, Convexity, Bond_age, Operating cash flow, ROA, Leverage, Intcov, Volatility, CEO_option, CEO_share, Per_inst, and Earnings quality have been winsorized at the $1^{\text {st }}$ and $99^{\text {th }}$ percentiles.

\begin{tabular}{|c|c|c|c|c|c|c|}
\hline \multicolumn{7}{|c|}{ Panel A: Summary Statistics } \\
\hline Variable & $\begin{array}{c}\text { Firm-year } \\
\text { Observations }\end{array}$ & $\mathrm{P} 25$ & Mean & Median & P75 & Std \\
\hline Spread (\%) & 1,494 & 1.19 & 2.68 & 1.73 & 2.98 & 3.52 \\
\hline Rate & 1,494 & 4 & 4.19 & 4 & 5 & 0.96 \\
\hline L-index & 1,494 & 0 & 1.02 & 1 & 2 & 0.96 \\
\hline L-dummy & 1,494 & 0 & 0.61 & 1 & 1 & 0.49 \\
\hline G-index & 1,494 & 8 & 10.21 & 10 & 12 & 2.44 \\
\hline Duration (years) & 1,494 & 0.09 & 0.15 & 0.12 & 0.17 & 0.12 \\
\hline Convexity (years) & 1,494 & 0.03 & 0.1 & 0.04 & 0.08 & 0.29 \\
\hline Bond_age (years) & 1,494 & 2.24 & 3.94 & 3.55 & 5.23 & 2.42 \\
\hline Operating cash flow & 1,494 & 0.08 & 0.11 & 0.11 & 0.15 & 0.06 \\
\hline ROA & 1,494 & 0.02 & 0.04 & 0.05 & 0.08 & 0.08 \\
\hline Loss & 1,494 & 0 & 0.06 & 0 & 0 & 0.23 \\
\hline Size (\$million) & 1,494 & $2,728.04$ & $28,569.63$ & $6,444.43$ & 17,018 & 108,822 \\
\hline Leverage & 1,494 & 0.18 & 0.28 & 0.26 & 0.36 & 0.15 \\
\hline Intcov & 1,494 & 4.54 & 12.27 & 8.26 & 14.18 & 15.51 \\
\hline Subord & 1,494 & 0 & 0.14 & 0 & 0 & 0.35 \\
\hline Volatility & 1,494 & 0.3 & 0.38 & 0.35 & 0.44 & 0.14 \\
\hline Cboard & 1,494 & 0 & 0.66 & 1 & 1 & 0.47 \\
\hline CEO_option & 1,494 & 0.14 & 0.36 & 0.36 & 0.55 & 0.26 \\
\hline CEO_share & 1,494 & 0 & 0.01 & 0 & 0.01 & 0.04 \\
\hline Per_dir_noshare & 1,494 & 0 & 0.04 & 0 & 0.08 & 0.08 \\
\hline Per_ind & 1,494 & 0.67 & 0.76 & 0.78 & 0.88 & 0.13 \\
\hline Board_size & 1,494 & 9 & 10.5 & 10 & 12 & 2.24 \\
\hline CEO_power & 1,494 & 2 & 2.55 & 3 & 4 & 1.22 \\
\hline Expert director & 1,494 & 0.43 & 0.58 & 0.6 & 0.75 & 0.23 \\
\hline Per_inst & 1,494 & 0.65 & 0.73 & 0.75 & 0.83 & 0.14 \\
\hline Blockholder & 1,494 & 1 & 1.89 & 2 & 3 & 1.31 \\
\hline Earnings quality & 1,494 & -0.05 & 0.08 & 0.11 & 0.26 & 0.32 \\
\hline \multicolumn{7}{|c|}{ Panel B: Change of L-index and G-index Over the Sample Period } \\
\hline \multicolumn{3}{|c|}{ Number of Firms } & $\begin{array}{l}\text { Number of Firms } \\
\text { Increasing index }\end{array}$ & $\begin{array}{l}\text { Number of Firms } \\
\text { Decreasing index }\end{array}$ & \multicolumn{2}{|c|}{$\begin{array}{l}\text { Number of Firms } \\
\text { Unchanging index }\end{array}$} \\
\hline \multirow[t]{2}{*}{$2002-2003$} & L-index & 1,206 & 9 & 18 & \multicolumn{2}{|r|}{1,179} \\
\hline & G-index & 1,206 & 420 & 112 & \multicolumn{2}{|r|}{674} \\
\hline \multirow[t]{2}{*}{ 2003-2005 } & L-index & 1,396 & 1 & 6 & \multicolumn{2}{|r|}{1,389} \\
\hline & G-index & 1,396 & 236 & 109 & \multicolumn{2}{|r|}{1,051} \\
\hline \multirow[t]{2}{*}{ 2005-2007 } & L-index & 1,391 & 10 & 2 & \multicolumn{2}{|r|}{1,379} \\
\hline & G-index & 1,391 & 161 & 203 & \multicolumn{2}{|r|}{1,027} \\
\hline
\end{tabular}


Panel C: Correlations

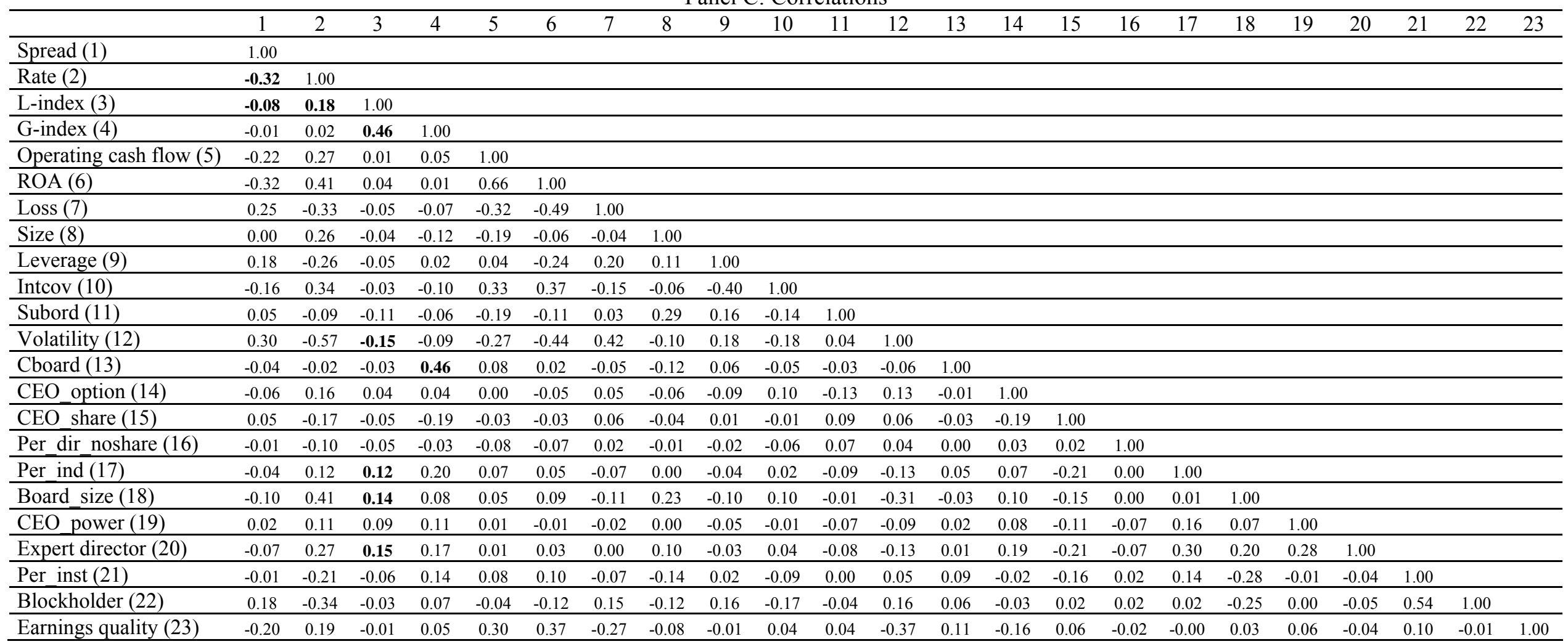




\section{Table 2. LLI Provisions and the Cost of Debt}

This table tests the effects of director limited liability and indemnification provisions on the cost of debt. Panel A presents the results of the t-tests for the difference of the cost of debt for firms without any LLI provisions, and firms with at least one LLI provision and matched by industry and firm size, or industry and credit rating between 2002 and 2007. Panel B reports the regression results of the LLI provisions on the cost of debt. The sample consists of the S\&P 1,500 firms between 2002 and 2007 with public senior unsecured bonds. The dependent variable for Model 1 is the firm's credit rating (Rate), defined by grouping S\&P long-term domestic issuer credit ratings (data280 in COMPUSTAT) into seven categories. See the Appendix for the details. The dependent variable for Model 2 is a dummy variable that equals one if the firm's credit rating is investment-grade (Rate $>=4$ ), and zero otherwise. Marginal effects, instead of coefficients are reported for ease of interpretation in this model. Remaining G-index equals G-index - L-index. The dependent variable for Models 3-5 is the bond spread, defined as the weighted average spread of all the senior unsecured bonds of the firm, with the weight being the issue size of the bond as a percentage of the total aggregate issue sizes of all outstanding bonds in the sample of the issuing firm in a given year. The spread for an individual bond is defined as the difference between the yield-to-maturity (YTM) of the bond and the YTM of the Treasury Bond matched by the closest maturity. See the Appendix for the definitions of other variables. Model 1 uses ordered-probit model. Model 2 uses probit model. Models 3-5 use pooled OLS model. All models include the Fama-French 48-industry and year dummies, and constant terms. Standard errors are adjusted for heteroscedasticity and clustered at the firm level. T-statistics are reported in parentheses. *, **, and *** indicate significance at the $10 \%, 5 \%$, and $1 \%$ levels, respectively.

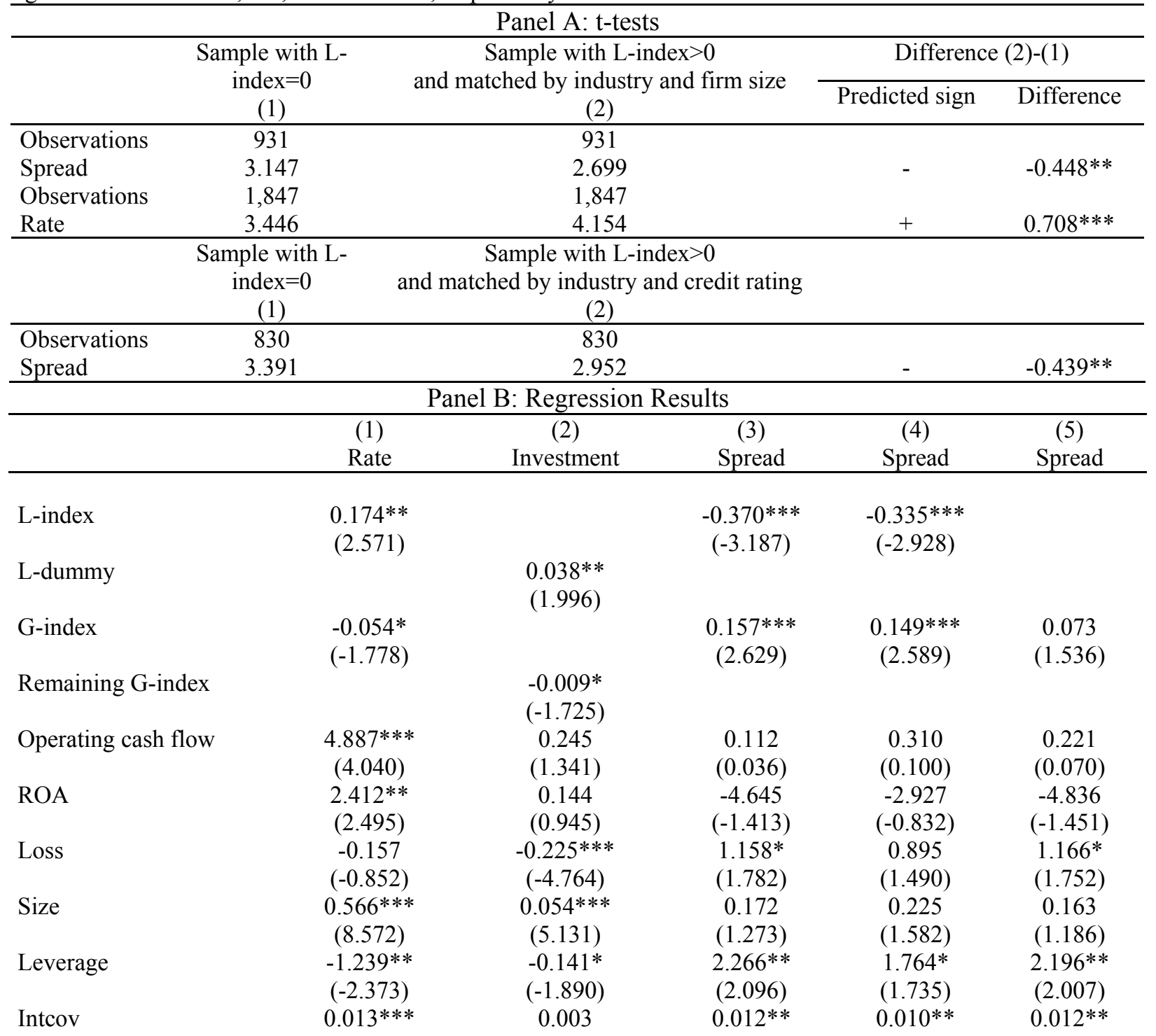




\begin{tabular}{|c|c|c|c|c|c|}
\hline & (3.189) & (1.528) & (2.088) & (1.978) & (2.166) \\
\hline \multirow[t]{2}{*}{ Subord } & $-0.249^{*}$ & $-0.128 * * *$ & -0.154 & -0.202 & -0.103 \\
\hline & $(-1.646)$ & $(-3.923)$ & $(-0.505)$ & $(-0.646)$ & $(-0.328)$ \\
\hline \multirow[t]{2}{*}{ Volatility } & $-5.681 * * *$ & $-0.592 * * *$ & $2.715^{* *}$ & 1.398 & $3.014 * * *$ \\
\hline & $(-9.651)$ & $(-7.932)$ & (2.450) & (1.217) & $(2.671)$ \\
\hline \multirow{2}{*}{ Cboard } & 0.035 & 0.019 & $-0.707 * * *$ & $-0.671 * * *$ & $-0.464 * *$ \\
\hline & $(0.264)$ & $(0.849)$ & $(-2.827)$ & $(-2.800)$ & $(-2.010)$ \\
\hline \multirow[t]{2}{*}{ CEO_option } & $0.572 * * *$ & $0.099 * * *$ & $-0.920 * *$ & -0.631 & $-0.941 * *$ \\
\hline & $(3.055)$ & $(3.080)$ & $(-2.274)$ & $(-1.520)$ & $(-2.324)$ \\
\hline \multirow[t]{2}{*}{ CEO_share } & $-3.247 * *$ & -0.159 & -0.018 & 0.517 & -0.997 \\
\hline & $(-2.051)$ & $(-0.728)$ & $(-0.007)$ & $(0.212)$ & $(-0.381)$ \\
\hline \multirow[t]{2}{*}{ Per_dir_noshare } & $-0.847^{*}$ & $-0.126^{* *}$ & -1.252 & -1.373 & -1.290 \\
\hline & $(-1.956)$ & $(-1.980)$ & $(-1.396)$ & $(-1.522)$ & $(-1.408)$ \\
\hline \multirow[t]{2}{*}{ Per_ind } & 0.315 & 0.037 & 0.187 & 0.238 & 0.249 \\
\hline & $(0.864)$ & $(0.675)$ & $(0.286)$ & $(0.372)$ & $(0.379)$ \\
\hline \multirow[t]{2}{*}{ Board_size } & $0.052 *$ & 0.002 & -0.052 & -0.054 & -0.061 \\
\hline & $(1.846)$ & $(0.575)$ & $(-0.864)$ & $(-0.916)$ & $(-0.988)$ \\
\hline \multirow[t]{2}{*}{ CEO_power } & -0.014 & -0.003 & 0.091 & 0.080 & 0.088 \\
\hline & $(-0.357)$ & $(-0.451)$ & $(1.121)$ & $(0.993)$ & (1.074) \\
\hline \multirow[t]{2}{*}{ Expert director } & 0.108 & 0.020 & -0.765 & -0.656 & -0.761 \\
\hline & $(0.420)$ & $(0.544)$ & $(-1.532)$ & $(-1.354)$ & $(-1.513)$ \\
\hline \multirow[t]{2}{*}{ Per_inst } & -0.517 & 0.063 & -1.149 & -0.541 & -0.943 \\
\hline & $(-1.011)$ & $(0.804)$ & $(-1.046)$ & $(-0.467)$ & $(-0.853)$ \\
\hline \multirow[t]{2}{*}{ Blockholder } & $-0.090^{* *}$ & $-0.018 * * *$ & $0.286^{* * *}$ & $0.268 * * *$ & $0.276 * * *$ \\
\hline & $(-2.096)$ & $(-2.664)$ & $(3.708)$ & $(3.579)$ & $(3.623)$ \\
\hline \multirow[t]{2}{*}{ Earnings quality } & $0.304^{*}$ & $0.041 *$ & $-1.377 * * *$ & $-1.367 * * *$ & $-1.357 * * *$ \\
\hline & $(1.822)$ & (1.649) & $(-3.091)$ & $(-3.061)$ & $(-3.004)$ \\
\hline \multirow[t]{2}{*}{ Duration } & & & $-14.217 * * *$ & $-13.949 * * *$ & $-14.435 * * *$ \\
\hline & & & $(-7.346)$ & $(-7.619)$ & $(-7.336)$ \\
\hline \multirow[t]{2}{*}{ Convexity } & & & $2.608^{* * *}$ & $2.587 * * *$ & $2.696 * * *$ \\
\hline & & & $(3.766)$ & $(4.057)$ & $(3.878)$ \\
\hline \multirow[t]{2}{*}{ Bond_age } & & & $0.191 * * *$ & $0.197 * * *$ & $0.177 * * *$ \\
\hline & & & $(4.314)$ & $(4.534)$ & $(4.034)$ \\
\hline \multirow[t]{2}{*}{ Rate2 } & & & & $-10.154 * * *$ & \\
\hline & & & & $(-2.700)$ & \\
\hline \multirow[t]{2}{*}{ Rate3 } & & & & $-10.643^{* * *}$ & \\
\hline & & & & $(-2.845)$ & \\
\hline \multirow[t]{2}{*}{ Rate4 } & & & & $-11.435 * * *$ & \\
\hline & & & & $(-3.044)$ & \\
\hline \multirow[t]{2}{*}{ Rate5 } & & & & $-11.723 * * *$ & \\
\hline & & & & $(-3.120)$ & \\
\hline \multirow[t]{2}{*}{ Rate6 } & & & & $-10.825 * * *$ & \\
\hline & & & & $(-2.849)$ & \\
\hline \multirow[t]{2}{*}{ Rate7 } & & & & $-11.150 * * *$ & \\
\hline & & & & $(-2.932)$ & \\
\hline Observations & 1,494 & 1,414 & 1,494 & 1,494 & 1,494 \\
\hline Pseudo $\mathrm{R}^{2}$ & 0.43 & 0.55 & & & \\
\hline Adjusted $\mathrm{R}^{2}$ & & & 0.35 & 0.37 & 0.34 \\
\hline
\end{tabular}




\section{Table 3. LLI Provisions and Corporate Risk Taking}

These models present the results of pooled OLS regressions for the effect of director limited liability and indemnification provisions on the risk-taking incentives of directors. The sample consists of the S\&P 1,500 firms over 2002 and 2007. The dependent variable for Model 1 is the R\&D expenses as a percentage of total assets. The dependent variable for Model 2 is the capital expenditure as a percentage of total assets. The dependent variable for Model 3 is the number of diversifying acquisitions the firm made in a given year, with a diversifying acquisition defined as the firm acquiring another firm not in the same industry as defined by the Fama-French 48 industries. The dependent variable for Model 4 is the standard deviation of monthly stock returns over the past 60 months. See the Appendix for the definitions of other variables. All models include Fama-French 48-industry and year dummies, and a constant term. Standard errors are adjusted for heteroscedasticity and clustered at the firm level. T-statistics are reported in parentheses. $*, * *$, and $* * *$ indicate significance at the $10 \%, 5 \%$, and $1 \%$ levels, respectively.

\begin{tabular}{|c|c|c|c|c|}
\hline & $\begin{array}{c}(1) \\
R \& D \\
\end{array}$ & $\begin{array}{c}(2) \\
\text { Capexp } \\
\end{array}$ & $\begin{array}{c}3) \\
\text { Numdaqr }\end{array}$ & $\begin{array}{c}(4) \\
\text { Volatility }\end{array}$ \\
\hline L-index & $\begin{array}{c}0.001 \\
(1.009)\end{array}$ & $\begin{array}{c}-0.003 * * * \\
(-3.023)\end{array}$ & $\begin{array}{c}0.027 * * \\
(2.330)\end{array}$ & $\begin{array}{c}-0.012 * * * \\
(-2.726)\end{array}$ \\
\hline G-index & $\begin{array}{c}-0.000 \\
(-1.189)\end{array}$ & $\begin{array}{c}0.000 \\
(0.302)\end{array}$ & $\begin{array}{l}-0.005 \\
(-1.358)\end{array}$ & $\begin{array}{c}-0.004 * * * \\
(-2.724)\end{array}$ \\
\hline Lagged Q & $\begin{array}{c}0.010 * * * \\
(8.687)\end{array}$ & $\begin{array}{c}0.005 * * * \\
(7.352)\end{array}$ & $\begin{array}{c}0.001 \\
(0.171)\end{array}$ & \\
\hline ROA & $\begin{array}{c}-0.144 * * * \\
(-9.865)\end{array}$ & $\begin{array}{l}0.013^{*} \\
(1.793)\end{array}$ & $\begin{array}{c}-0.040 \\
(-0.823)\end{array}$ & $\begin{array}{c}-0.253 * * * \\
(-9.311)\end{array}$ \\
\hline Size & $\begin{array}{c}-0.005 * * * \\
(-6.330)\end{array}$ & $\begin{array}{c}-0.002 * * * \\
(-2.724)\end{array}$ & $\begin{array}{c}0.040^{* * * *} \\
(4.463)\end{array}$ & $\begin{array}{c}-0.017 * * * \\
(-5.650)\end{array}$ \\
\hline Leverage & $\begin{array}{c}-0.017 * * * \\
(-2.636)\end{array}$ & $\begin{array}{c}-0.002 \\
(-0.471)\end{array}$ & $\begin{array}{c}-0.038 \\
(-0.794)\end{array}$ & $\begin{array}{c}-0.011 \\
(-0.463)\end{array}$ \\
\hline Cashflow & $\begin{array}{c}-0.001 \\
(-0.846)\end{array}$ & $\begin{array}{c}-0.001 * * * \\
(-2.778)\end{array}$ & $\begin{array}{c}-0.003 \\
(-1.061)\end{array}$ & \\
\hline Acquirer & & & $\begin{array}{c}0.716^{* * *} \\
(27.495)\end{array}$ & \\
\hline Board_size & & & & $\begin{array}{c}-0.010 * * * \\
(-5.914)\end{array}$ \\
\hline Per_ind & & & & $\begin{array}{l}-0.037 * \\
(-1.697)\end{array}$ \\
\hline CEO_power & & & & $\begin{array}{c}-0.006^{* *} \\
(-2.510)\end{array}$ \\
\hline ROA at $t-1$ & & & & $\begin{array}{c}-0.218 * * * \\
(-5.982)\end{array}$ \\
\hline $\mathrm{ROA}$ at $\mathrm{t}-2$ & & & & $\begin{array}{c}-0.156 * * * \\
(-3.955)\end{array}$ \\
\hline Capexp & & & & $\begin{array}{c}0.024 \\
(0.282)\end{array}$ \\
\hline Firm_age & & & & $\begin{array}{c}-0.001 * * * \\
(-3.861)\end{array}$ \\
\hline Segment & & & & $\begin{array}{c}0.001 \\
(1.034)\end{array}$ \\
\hline Observations & 7,225 & 7,225 & 7,225 & 5,665 \\
\hline Adjusted $\mathrm{R}^{2}$ & 0.55 & 0.39 & 0.33 & 0.56 \\
\hline
\end{tabular}




\section{Table 4. LLI Provisions, Growth Opportunities, and Corporate Risk Taking}

These models present the results of pooled OLS regressions for the effect of director limited liability and indemnification provisions on the risk-taking incentives of the board, conditional on a firm's growth opportunities. The sample consists of the S\&P 1,500 firms over 2002 and 2007. The dependent variable for Model 1 is the R\&D expenses as a percentage of total assets. The dependent variable for Model 2 is the capital expenditure as a percentage of total assets. The dependent variable for Model 3 is the number of diversifying acquisitions the firm made in a given year, with a diversifying acquisition defined as the firm acquiring another firm not in the same industry as defined by the Fama-French 48 industries. The dependent variable for Model 4 is the standard deviation of monthly stock returns over the past 60 months. High lagged Q is a dummy variable that equals one if the lagged Tobin's $Q$ is above the sample median, and zero otherwise. See the Appendix for the definitions of other variables. All models include the control variables as in the corresponding models in Table 3, the Fama-French 48-industry and year dummies, and a constant term. These variables are omitted to save space. Standard errors are adjusted for heteroscedasticity and clustered at the firm level. T-statistics are reported in parentheses. $*, * *$, and $* * *$ indicate significance at the $10 \%, 5 \%$, and $1 \%$ levels, respectively.

\begin{tabular}{lcccc}
\hline & $(1)$ & $(2)$ & $(3)$ & $(4)$ \\
& R\&D & Capexp & Numdaqr & Volatility \\
\hline & & & & \\
L-index & $0.003^{* * *}$ & $-0.004^{* * *}$ & 0.010 & -0.006 \\
& $(3.208)$ & $(-3.124)$ & $(0.727)$ & $(-1.226)$ \\
High lagged Q ${ }^{*}$ L-index & $-0.004^{*}$ & 0.002 & $0.037^{*}$ & $-0.015^{* *}$ \\
High lagged Q & $(-1.814)$ & $(0.922)$ & $(1.805)$ & $(-2.215)$ \\
& 0.009 & $0.012^{* *}$ & 0.077 & 0.024 \\
G-index & $(1.625)$ & $(2.468)$ & $(1.287)$ & $(1.028)$ \\
& -0.000 & 0.000 & -0.003 & $-0.003^{*}$ \\
High lagged Q $*$ G-index & $(-1.589)$ & $(0.863)$ & $(-0.693)$ & $(-1.872)$ \\
& 0.000 & -0.000 & -0.003 & -0.001 \\
Observations & $(0.477)$ & $(-0.618)$ & $(-0.483)$ & $(-0.242)$ \\
Adjusted $\mathrm{R}^{2}$ & 7,225 & 7,225 & 7,225 & 5,103 \\
& 0.56 & 0.40 & 0.33 & 0.55 \\
\hline
\end{tabular}




\section{Table 5. LLI Provisions, Directorial Incentives, and the Cost of Debt}

These models present the results of pooled OLS regressions for the effect of director limited liability and indemnification provisions on bond spreads conditional on a firm's closeness to financial default and agency costs. The sample consists of the S\&P 1,500 firms between 2002 and 2007 with public senior unsecured bonds. The dependent variable for all the models is the bond spread, defined as the weighted average spread of all the senior unsecured bonds of the firm, with the weight being the issue size of the bond as a percentage of the total aggregate issue sizes of all the outstanding bonds in the sample of the issuing firm in a given year. The spread for an individual bond is defined as the difference between the yield-to-maturity (YTM) of the bond and the YTM of the Treasury Bond matched by the closest maturity. Speculative is a dummy variable that equals one if the credit rating is speculative-grade (Rate $<4)$, and zero otherwise. Low Z-score is dummy variable that equals one if the firm's Altman's Z-score is at or below the sample median, and zero otherwise. High free cash flow is a dummy variable that equals one if the firm's free cash flow is above the sample median, and zero otherwise, where the calculation of free cash flow follows Lehn and Poulsen (1989). No blockholder is a dummy that equals one if the firm does not have an institutional blockholder with at least 5\% ownership, and zero otherwise. See the Appendix for the definitions of other variables. All models use pooled OLS regressions and include the control variables as in Model 3 of Table 2, the Fama-French 48-industry and year dummies, and a constant term. These variables are omitted to save space. Standard errors are adjusted for heteroscedasticity and clustered at the firm level. T-statistics are reported in parentheses. *, $* *$, and $* * *$ indicate significance at the $10 \%, 5 \%$, and $1 \%$ levels, respectively.

\begin{tabular}{|c|c|c|c|c|c|}
\hline & $\begin{array}{c}(1) \\
\text { Spread }\end{array}$ & $\begin{array}{c}(2) \\
\text { Spread }\end{array}$ & $\begin{array}{c}(3) \\
\text { Spread } \\
\end{array}$ & $\begin{array}{c}(4) \\
\text { Spread }\end{array}$ & $\begin{array}{c}(5) \\
\text { Spread }\end{array}$ \\
\hline L-index & $\begin{array}{c}-0.316^{* *} \\
(-2.377)\end{array}$ & $\begin{array}{c}0.013 \\
(0.099)\end{array}$ & $\begin{array}{c}-0.379 * * * \\
(-3.265)\end{array}$ & $\begin{array}{c}-0.580 * * * \\
(-3.121)\end{array}$ & $\begin{array}{c}-0.499 * * * \\
(-3.759)\end{array}$ \\
\hline Speculative * L-index & $\begin{array}{c}-0.137 \\
(-0.476)\end{array}$ & & & & \\
\hline Speculative & $\begin{array}{c}0.845 \\
(0.770)\end{array}$ & & & & \\
\hline G-index & $\begin{array}{c}0.150 * * \\
(2.564)\end{array}$ & $\begin{array}{c}-0.034 \\
(-0.501)\end{array}$ & $\begin{array}{c}0.146^{* *} \\
(2.494)\end{array}$ & $\begin{array}{c}0.184 * * \\
(2.218)\end{array}$ & $\begin{array}{c}0.171 * * * \\
(2.655)\end{array}$ \\
\hline Speculative * G-index & $\begin{array}{c}0.019 \\
(0.152)\end{array}$ & & & & \\
\hline Low Z-score * L-index & & $\begin{array}{c}-0.408^{* *} \\
(-2.021)\end{array}$ & & & \\
\hline Low Z-score & & $\begin{array}{l}-2.217^{*} \\
(-1.848)\end{array}$ & & & \\
\hline Low Z-score * G-index & & $\begin{array}{c}0.245^{* *} \\
(2.193)\end{array}$ & & & \\
\hline PPS & & & $\begin{array}{c}-1.259 * * * \\
(-2.971)\end{array}$ & $\begin{array}{c}-1.279 * * * \\
(-3.141)\end{array}$ & $\begin{array}{c}-1.280^{* * *} \\
(-3.086)\end{array}$ \\
\hline High free cash flow $*$ L-index & & & & $\begin{array}{l}0.406^{*} \\
(1.955)\end{array}$ & \\
\hline High free cash flow & & & & $\begin{array}{c}0.483 \\
(0.630)\end{array}$ & \\
\hline High free cash flow $*$ G-index & & & & $\begin{array}{l}-0.084 \\
(-1.041)\end{array}$ & \\
\hline No blockholder $*$ L-index & & & & & $\begin{array}{c}0.688 * * * \\
(3.091)\end{array}$ \\
\hline No blockholder & & & & & $\begin{array}{c}0.168 \\
(0.211)\end{array}$ \\
\hline No blockholder $*$ G-index & & & & & $\begin{array}{c}-0.050 \\
(-0.628)\end{array}$ \\
\hline Observations & 1,494 & 823 & 1,487 & 1,484 & 1,487 \\
\hline Adjusted $\mathrm{R}^{2}$ & 0.35 & 0.43 & 0.35 & 0.35 & 0.35 \\
\hline
\end{tabular}




\section{Table 6. LLI Provisions and Directorial Shirking}

These models present the results of panel regressions for the effect of director limited liability and indemnification provisions on CEO turnover-performance sensitivity (TPS) and pay-performance sensitivity (PPS). The sample consists of the S\&P 1,500 firms and covers years from 2002 to 2006 for the TPS regression, and from 2002 to 2007 for the PPS regression. The dependent variable for Model 1 is the CEO turnover, defined as a dummy variable that equals one if the current CEO is no longer the CEO next year, and zero otherwise. Firms which are the takeover targets are deleted from the sample in Model 1. The dependent variable for Model 2 is the change of CEO total compensation over previous year in $\$ 100,000$ s. Firms whose CEOs have experienced turnover in current or previous year, or whose CEOs' tenure is less than two years are deleted from the sample. High L-index (G-index) is a dummy variable that equals one if the firm's L-index (G-index) is above the sample median, and zero otherwise. $\Delta$ denotes the change of a variable over previous year. See the Appendix for the definitions of other variables. Both models include the Fama-French 48-industry and year dummies, and a constant term. Model 1 uses probit model. Model 2 uses pooled OLS model. Standard errors are adjusted for heteroscedasticity and clustered at the firm level. Tstatistics are reported in parentheses. *,**, and *** indicate significance at the $10 \%, 5 \%$, and $1 \%$ levels, respectively.

CEO turnover

L-index

Return * High L-index

G-index

Return * High G-index

Return

$\Delta \mathrm{SW}$

$\Delta \mathrm{SW} *$ High L-index

$\Delta \mathrm{SW} *$ High G-index

CEO_share

CEO_power

CEO_tenure

CEO_age

Per_ind

Board_size

Per_inst

Size

Volatility

$\Delta$ Per_ind

$\Delta$ Board_size

$-3.184 * * *$

$(-2.903)$

$0.081^{* * * *}$

(2.835)

$-0.005$

$(-0.927)$

$0.017^{* * *}$

(3.315)

$-0.155$

$(-0.642)$

$0.059 * * *$

(3.263)

$0.439 * *$

(1.991)

$-0.037$

$(-1.355)$

0.206

(0.943)
(1)

$$
\begin{gathered}
-0.003 \\
(-0.080) \\
-0.034 \\
(-0.164) \\
-0.008 \\
(-0.530) \\
-0.169 \\
(-0.861)
\end{gathered}
$$

$-0.348^{* * *}$

$(-2.807)$

(2)

$\triangle \mathrm{CEO}$ compensation

0.141

0.277

(0.996)

$0.003 * * *$

$-0.002 * *$

$(-2.190)$

$0.003 * * *$

(2.859) 
$\Delta$ Per inst

$\Delta$ Size

$\Delta$ Volatility

$\triangle \mathrm{ROA}$

$\Delta \mathrm{Mb}$

Observations

Pseudo $\mathrm{R}^{2}$

Adjusted $\mathrm{R}^{2}$
$(-0.252)$

4.753

(0.605)

$12.523 * *$

(2.543)

4.289

(0.338)

$-4.087$

$(-0.516)$

0.431

(0.358)

4,237

0.06

4,202

0.04 


\section{Table 7. LLI Provisions and Litigation Risk and Firm Performance}

These models present the regression results for litigation risk on the number of director limited liability and indemnification provisions, the effect of the cost of debt on firm performance, and the effect of the LLI provisions on firm performance. The samples for Models 1 and 4 consist of the S\&P 1,500 firms over 2002 and 2007. The sample for Model 2 consists of the S\&P 1,500 firms between 2002 and 2006 with public senior unsecured bonds. The sample for Model 3 consists of the S\&P 1,500 firms between 2002 and 2007 with public senior unsecured bonds. The dependent variable for Model 1 is the number of director limited liability and indemnification provisions at the firm level. The dependent variable for Model 2 is the change of Tobin's Q over previous year. The dependent variable for Models 3 and 4 is Tobin's Q. "Predicted reduction of the cost of debt due to L-index" is the predicted component of the bond spread due to the L-index based on Model 3 of Table 2 (without the negative sign), scaled by total bond spread. $\Delta$ denotes the change of a variable over previous year. See the Appendix for the definitions of other variables. All models include a constant term. Models 1, 3, and 4 further include the Fama-French 48-industry and year dummies. The coefficient for Z-score has been multiplied by 1,000. Standard errors are adjusted for heteroscedasticity and clustered at the firm level. T-statistics are reported in parentheses. *, **, and *** indicate significance at the $10 \%, 5 \%$, and $1 \%$ levels, respectively.

\begin{tabular}{|c|c|c|c|c|}
\hline 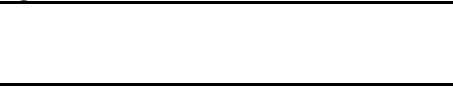 & $\begin{array}{c}(1) \\
\text { L-index } \\
\end{array}$ & $\begin{array}{l}(2) \\
\Delta \mathrm{Q} \\
\end{array}$ & $\begin{array}{l}(3) \\
Q\end{array}$ & $\begin{array}{l}(4) \\
Q \\
\end{array}$ \\
\hline Size & $\begin{array}{c}0.128 * * * \\
(6.537)\end{array}$ & & $\begin{array}{c}-0.168 * * * \\
(-3.598)\end{array}$ & $\begin{array}{c}-0.195 * * * \\
(-6.097)\end{array}$ \\
\hline Z-score & $\begin{array}{c}-0.003 * * * \\
(-3.369)\end{array}$ & & & \\
\hline MB & $\begin{array}{c}0.019 \\
(0.973)\end{array}$ & & & \\
\hline Shareholder & $\begin{array}{c}0.094 * * * \\
(4.282)\end{array}$ & & & \\
\hline$\Delta$ Spread & & $\begin{array}{c}-0.004 * * * \\
(-2.806)\end{array}$ & & \\
\hline$\Delta$ Rate & & $\begin{array}{l}0.062 * * \\
(2.055)\end{array}$ & & \\
\hline $\begin{array}{l}\text { Predicted reduction of the cost } \\
\text { of debt due to L-index }\end{array}$ & & & $\begin{array}{l}0.015^{* *} \\
(2.140)\end{array}$ & \\
\hline L-index & & & & $\begin{array}{c}0.012 \\
(0.377)\end{array}$ \\
\hline G-index & & & $\begin{array}{r}-0.015^{* *} \\
(-2.016)\end{array}$ & $\begin{array}{c}-0.021 * * \\
(-2.373)\end{array}$ \\
\hline$\triangle \mathrm{ROA}$ & & $\begin{array}{c}1.159 * * * \\
(3.857)\end{array}$ & & \\
\hline$\Delta$ Size & & $\begin{array}{c}-0.619 * * * \\
(-4.753)\end{array}$ & & \\
\hline$\Delta$ Intangible & & $\begin{array}{l}-0.348 \\
(-0.852)\end{array}$ & & \\
\hline$\Delta$ Leverage & & $\begin{array}{c}0.359 \\
(1.210)\end{array}$ & & \\
\hline$\Delta \mathrm{R} \& \mathrm{D}$ & & $\begin{array}{c}-2.269 \\
(-0.821)\end{array}$ & & \\
\hline$\Delta$ Capexp & & $\begin{array}{c}2.002 * * * \\
(3.631)\end{array}$ & & \\
\hline$\Delta$ Segment & & $\begin{array}{c}0.001 \\
(0.236)\end{array}$ & & \\
\hline ROA & & & $\begin{array}{l}5.004 * * * \\
(5.711)\end{array}$ & $\begin{array}{c}2.386 * * * \\
(7.616)\end{array}$ \\
\hline Intangible & & & $\begin{array}{l}0.313^{*} \\
(1.818)\end{array}$ & $\begin{array}{c}0.897 * * * \\
(5.594)\end{array}$ \\
\hline Leverage & & & $0.817^{* *}$ & 0.107 \\
\hline
\end{tabular}




\begin{tabular}{|c|c|c|c|c|}
\hline \multirow[b]{2}{*}{$R \& D$} & & & (2.384) & $(0.541)$ \\
\hline & & & $\begin{array}{c}10.989 * * * \\
(6.030)\end{array}$ & $\begin{array}{c}5.604 * * * \\
(8.594)\end{array}$ \\
\hline Capexp & & & $\begin{array}{c}2.405^{* * * *} \\
(3.319)\end{array}$ & $\begin{array}{c}4.923 * * * \\
(8.481)\end{array}$ \\
\hline Firm_age & & & $\begin{array}{l}-0.000 \\
(-0.379)\end{array}$ & $\begin{array}{c}-0.002 \\
(-0.971)\end{array}$ \\
\hline Segment & & & $\begin{array}{c}0.006 \\
(0.817)\end{array}$ & $\begin{array}{c}-0.007 \\
(-0.938)\end{array}$ \\
\hline SP500 & & & $\begin{array}{c}0.339 * * * \\
(4.684)\end{array}$ & $\begin{array}{c}0.837 * * * \\
(8.483)\end{array}$ \\
\hline Observations & 5,397 & 1,628 & 2,208 & 7,297 \\
\hline Adjusted R2 & 0.14 & 0.14 & 0.53 & 0.36 \\
\hline
\end{tabular}


Table 8. LLI Provisions and Attraction and Retention of Talented Directors

These models present the results of pooled OLS regressions for the effect of director limited liability and indemnification provisions on the attraction and retention of talented directors during the sample period. The sample for Model 1 consists of the S\&P 1,500 firms between 2002 and 2006. The samples for Models 2-5 consist of the S\&P 1,500 firms between 2002 and 2007. The dependent variable for Model 1 is the number of departing directors as a fraction of board size in a given year. The dependent variable for Model 2 is the number of newly added directors as a fraction of board size. The dependent variable for Model 3 is the average number of outside directorships for newly added directors. The dependent variable for Model 4 is the average number of outside directorships for the whole board. The dependent variable for Model 5 is the number of independent directors who are active executives of other firms as a fraction of board size. See the Appendix for the definitions of other variables. $\Delta$ denotes the change of a variable over previous year. Firms which are the takeover targets are deleted from the samples for Models 1 and 2. All models include the Fama-French 48-industry and year dummies, and a constant term. Standard errors are adjusted for heteroscedasticity and clustered at the firm level. T-statistics are reported in parentheses. $*$, **, and $* * *$ indicate significance at the $10 \%, 5 \%$, and $1 \%$ levels, respectively.

\begin{tabular}{|c|c|c|c|c|c|}
\hline & $\begin{array}{c}(1) \\
\text { Dpt_dir }\end{array}$ & $\begin{array}{c}(2) \\
\text { Add_dir }\end{array}$ & $\begin{array}{c}\text { (3) } \\
\text { Add_dirship }\end{array}$ & $\begin{array}{c}\text { (4) } \\
\text { Dirship }\end{array}$ & $\begin{array}{c}(5) \\
\text { Per_ie }\end{array}$ \\
\hline L-index & $\begin{array}{c}0.001 \\
(0.285)\end{array}$ & $\begin{array}{c}0.002 \\
(0.748)\end{array}$ & $\begin{array}{c}-0.046 \\
(-1.535)\end{array}$ & $\begin{array}{c}-0.007 \\
(-0.445)\end{array}$ & $\begin{array}{c}-0.003 \\
(-1.065)\end{array}$ \\
\hline G-index & $\begin{array}{c}0.000 \\
(0.056)\end{array}$ & $\begin{array}{c}-0.000 \\
(-0.031)\end{array}$ & $\begin{array}{c}0.013 \\
(1.176)\end{array}$ & $\begin{array}{c}0.011 * * \\
(2.010)\end{array}$ & $\begin{array}{c}0.003 * * * \\
(2.892)\end{array}$ \\
\hline Return & $\begin{array}{c}-0.012 * * * \\
(-2.627)\end{array}$ & $\begin{array}{l}0.008^{*} \\
(1.848)\end{array}$ & $\begin{array}{c}-0.013 \\
(-0.191)\end{array}$ & $\begin{array}{c}-0.027 \\
(-1.377)\end{array}$ & \\
\hline Return at $\mathrm{t}-1$ & $\begin{array}{c}-0.010 * * \\
(-2.482)\end{array}$ & $\begin{array}{c}-0.003 \\
(-0.652)\end{array}$ & $\begin{array}{c}-0.088 \\
(-1.508)\end{array}$ & $\begin{array}{l}-0.030^{*} \\
(-1.665)\end{array}$ & \\
\hline Return at $\mathrm{t}-2$ & $\begin{array}{c}-0.003 \\
(-0.911)\end{array}$ & $\begin{array}{c}-0.002 \\
(-0.474)\end{array}$ & $\begin{array}{c}-0.006 \\
(-0.110)\end{array}$ & $\begin{array}{l}-0.023^{*} \\
(-1.722)\end{array}$ & \\
\hline ROA & $\begin{array}{l}-0.020 \\
(-0.987)\end{array}$ & $\begin{array}{c}-0.011 \\
(-0.807)\end{array}$ & $\begin{array}{c}-0.008 \\
(-0.041)\end{array}$ & $\begin{array}{c}-0.277 * * * \\
(-3.315)\end{array}$ & \\
\hline Size & $\begin{array}{c}0.001 \\
(0.984)\end{array}$ & $\begin{array}{c}0.004 * * * \\
(2.884)\end{array}$ & $\begin{array}{c}0.140 * * * \\
(5.878)\end{array}$ & $\begin{array}{c}0.172 * * * \\
(15.616)\end{array}$ & $\begin{array}{c}0.012 * * * \\
(6.193)\end{array}$ \\
\hline Dir_age & $\begin{array}{c}0.002 * * * \\
(3.253)\end{array}$ & $\begin{array}{c}-0.001 \\
(-1.467)\end{array}$ & $\begin{array}{c}0.018^{* *} \\
(2.072)\end{array}$ & $\begin{array}{c}0.017 * * * \\
(3.787)\end{array}$ & \\
\hline Dir_tenure & $\begin{array}{c}-0.001 * * * \\
(-3.069)\end{array}$ & $\begin{array}{c}-0.004 * * \\
(-2.141)\end{array}$ & $\begin{array}{l}-0.008^{*} \\
(-1.713)\end{array}$ & $\begin{array}{c}-0.015^{* * *} \\
(-2.906)\end{array}$ & \\
\hline Dirship & $\begin{array}{l}0.006^{*} \\
(1.677)\end{array}$ & $\begin{array}{c}-0.002 \\
(-0.607)\end{array}$ & & & \\
\hline Dir_share & $\begin{array}{c}0.001 \\
(0.042)\end{array}$ & $\begin{array}{c}0.008 \\
(0.456)\end{array}$ & $\begin{array}{c}0.164 \\
(0.683)\end{array}$ & $\begin{array}{c}0.107 \\
(0.536)\end{array}$ & \\
\hline CEO out & $\begin{array}{c}0.013^{* * *} \\
(3.787)\end{array}$ & $\begin{array}{c}0.011^{* * *} \\
(3.568)\end{array}$ & & & \\
\hline$\Delta$ Per_inst & $\begin{array}{l}0.033^{*} \\
(1.661)\end{array}$ & $\begin{array}{c}0.041 * * \\
(2.501)\end{array}$ & & & \\
\hline $\mathrm{Mb}$ & & & $\begin{array}{l}0.051^{*} \\
(1.750)\end{array}$ & $\begin{array}{c}0.036 * * * \\
(2.960)\end{array}$ & $\begin{array}{c}0.004 * * \\
(2.154)\end{array}$ \\
\hline Board_size & & & $\begin{array}{c}-0.032 * * \\
(-2.327)\end{array}$ & $\begin{array}{c}-0.026^{* * *} \\
(-4.373)\end{array}$ & \\
\hline Interlock & & & $\begin{array}{l}-0.189^{*} \\
(-1.849)\end{array}$ & $\begin{array}{l}0.105^{*} \\
(1.917)\end{array}$ & \\
\hline Num_oe & & & $\begin{array}{c}0.197 * * * \\
(5.086)\end{array}$ & $\begin{array}{c}0.271 * * * \\
(14.920)\end{array}$ & \\
\hline Per_noe & & & $\begin{array}{c}0.351 \\
(1.048)\end{array}$ & $\begin{array}{c}0.877 * * * \\
(7.223)\end{array}$ & \\
\hline Blk_idir & & & $\begin{array}{l}0.221^{*} \\
(1.671)\end{array}$ & $\begin{array}{l}-0.082^{*} \\
(-1.686)\end{array}$ & \\
\hline
\end{tabular}


Blockholder

Idir share

Firm_age

Segment

R\&D

Leverage

CEO share

CEO tenure

CEO age

Lagged board_size

M\&A at t-1

ROA at $\mathrm{t}-1$

Observations

Adjusted $\mathrm{R}^{2}$

$\begin{array}{cc}0.025 & 0.015^{* *} \\ (1.143) & (2.020)\end{array}$

$-0.042$

$(-1.164)$

$0.001 * * *$

(5.112)

$-0.001$

$(-0.842)$

0.050

$(0.935)$

$-0.024 *$

$(-1.941)$

$-0.005$

$(-0.152)$

$-0.002 * * *$

$(-5.799)$

$-0.000$

$(-0.262)$

$-0.000$

$(-0.356)$

0.000

(0.077)

0.009

(0.819)

3,329

0.17 


\section{Table 9. First-Difference Regression: LLI Provisions and the Cost of Debt}

These models present the change regression results of the director limited liability and indemnification provisions on bond spreads. The samples are obtained by matching firms that changed their L-index with firms that kept their Lindex constant between 2002 and 2007 by industry (according to Fama-French 48 industries) and either firm size, or book leverage ratio, or equity volatility, or credit rating. The dependent variable for each model is the change of the bond spread over previous year, where bond spread is defined as the weighted average spread of all the senior unsecured bonds of the firm, with the weight being the issue size of the bond as a percentage of the total aggregate issue sizes of all outstanding bonds in the sample of the issuing firm in a given year. The spread for an individual bond is defined as the difference between the yield-to-maturity (YTM) of the bond and the YTM of the Treasury Bond matched by the closest maturity. See the Appendix for the definitions of other variables. All models also include a constant term. Standard errors are adjusted for heteroscedasticity and clustered at the firm level. Tstatistics are reported in parentheses. *, **, and *** indicate significance at the $10 \%, 5 \%$, and $1 \%$ levels, respectively.

(1) $\Delta$ Spread

\begin{tabular}{cc}
\hline Sample & Firms with $\Delta \mathrm{L}$-index \\
& $\neq 0$ matched with $\Delta \mathrm{L}-$ \\
& index $=0$ by industry \\
& and firm size
\end{tabular}

(2) $\Delta$ Spread Firms with $\Delta \mathrm{L}$-index $\neq 0$ matched with $\Delta \mathrm{L}-$ index $=0$ by industry and leverage
(3) $\Delta$ Spread
(4)
$\Delta$ Spread

\begin{tabular}{lcccc}
$\Delta \mathrm{L}$-index & $-1.615^{* *}$ & $-1.904^{* * *}$ & $-1.744^{* *}$ & $-1.359^{* *}$ \\
& $(-2.341)$ & $(-3.433)$ & $(-2.502)$ & $(-2.178)$ \\
$\Delta \mathrm{G}-$-index & $1.229^{* *}$ & $1.472^{* * *}$ & $1.322^{* *}$ & $1.086^{* *}$ \\
& $(2.390)$ & $(3.512)$ & $(2.601)$ & $(2.273)$ \\
Observations & 36 & 36 & 34 & 36 \\
Adjusted R2 & 0.13 & 0.38 & 0.11 & 0.15 \\
\hline
\end{tabular}




\section{Table 10. 2SLS Regression: Credit Ratings and Bond Spreads}

This table reports the results of the simultaneous equations estimation for credit ratings and bond spreads. The sample consists of the S\&P 1,500 firms between 2002 and 2007 with public senior unsecured bonds. The dependent variable for Model 1is the firm's credit rating (Rate), defined by grouping S\&P long-term domestic issuer credit ratings (data280 in COMPUSTAT) into seven categories. See the Appendix for the details. The dependent variable for Model 2 is the bond spread, defined as the weighted average spread of all the senior unsecured bonds of the firm, with the weight being the issue size of the bond as a percentage of the total aggregate issue sizes of all outstanding bonds in the sample of the issuing firm in a given year. The spread for an individual bond is defined as the difference between the yield-to-maturity (YTM) of the bond and the YTM of the Treasury Bond matched by closest maturity. See the Appendix for the definitions of other variables. Both models include the Fama-French 48-industry and year dummies, and a constant term. Standard errors are adjusted for heteroscedasticity and clustered at the firm level. T-statistics are reported in parentheses. ${ }^{*}, * *$, and $* * *$ indicate significance at the $10 \%, 5 \%$, and $1 \%$ levels, respectively.

(1) (2)

Rate

Rate Spread

\begin{tabular}{|c|c|c|}
\hline Rate & & $\begin{array}{c}-0.041 \\
(-0.196)\end{array}$ \\
\hline L-index & $\begin{array}{l}0.020^{*} \\
(1.898)\end{array}$ & $\begin{array}{c}-0.363 * * * \\
(-3.115)\end{array}$ \\
\hline G-index & $\begin{array}{c}-0.005 \\
(-0.981)\end{array}$ & $\begin{array}{c}0.146^{* *} \\
(2.476)\end{array}$ \\
\hline Spread & $\begin{array}{c}-0.021 * * * \\
(-3.186)\end{array}$ & \\
\hline Lagged rate & $\begin{array}{c}0.813 * * * \\
(47.747)\end{array}$ & \\
\hline Duration & & $\begin{array}{r}-14.131 * * \\
(-7.413)\end{array}$ \\
\hline Convexity & & $\begin{array}{c}2.564 * * * \\
(3.821)\end{array}$ \\
\hline Bond_age & & $\begin{array}{c}0.185^{* * *} \\
(4.308)\end{array}$ \\
\hline Operating cash flow & $\begin{array}{c}0.619 * * \\
(2.022)\end{array}$ & $\begin{array}{l}-3.788^{*} \\
(-1.927)\end{array}$ \\
\hline ROA & $\begin{array}{c}0.995^{* * *} \\
(2.890)\end{array}$ & $\begin{array}{c}-0.141 \\
(-0.068)\end{array}$ \\
\hline Loss & $\begin{array}{c}0.057 \\
(1.076)\end{array}$ & $\begin{array}{c}1.585^{* * *} \\
(2.644)\end{array}$ \\
\hline Size & $\begin{array}{c}0.046 * * * \\
(4.131)\end{array}$ & $\begin{array}{c}0.157 \\
(1.107)\end{array}$ \\
\hline Leverage & $\begin{array}{c}-0.144 \\
(-1.481)\end{array}$ & $\begin{array}{c}2.270^{* * *} \\
(2.126)\end{array}$ \\
\hline Intcov & $\begin{array}{c}0.001 \\
(1.591)\end{array}$ & $\begin{array}{c}0.012 * * \\
(2.123)\end{array}$ \\
\hline Subord & $\begin{array}{c}0.007 \\
(0.270)\end{array}$ & $\begin{array}{c}-0.082 \\
(-0.280)\end{array}$ \\
\hline Volatility & $\begin{array}{c}-0.313^{* * *} \\
(-2.649)\end{array}$ & $\begin{array}{c}2.700^{* *} \\
(2.376)\end{array}$ \\
\hline Cboard & $\begin{array}{c}0.006 \\
(0.299)\end{array}$ & $\begin{array}{c}-0.593 * * \\
(-2.501)\end{array}$ \\
\hline CEO_option & $\begin{array}{c}0.067 \\
(1.637)\end{array}$ & $\begin{array}{c}-0.888 * * \\
(-2.193)\end{array}$ \\
\hline CEO_share & $\begin{array}{c}-0.499 * * \\
(-2.241)\end{array}$ & $\begin{array}{c}-0.611 \\
(-0.257)\end{array}$ \\
\hline Per_dir_noshare & -0.108 & -1.167 \\
\hline
\end{tabular}




\begin{tabular}{lcc} 
& $(-1.174)$ & $(-1.368)$ \\
Per_ind & -0.033 & 0.187 \\
& $(-0.476)$ & $(0.298)$ \\
Board_size & -0.001 & -0.039 \\
& $(-0.286)$ & $-0.672)$ \\
CEO_power & -0.008 & 0.097 \\
& $(-1.065)$ & $(1.221)$ \\
Expert director & -0.028 & -0.693 \\
& $(-0.664)$ & $(-1.426)$ \\
Per_inst & 0.158 & -1.407 \\
& $(1.397)$ & $(-1.330)$ \\
Blockholder & $-0.022^{* *}$ & $0.299^{* * *}$ \\
& $(-2.404)$ & $(4.001)$ \\
Earnings quality & 0.064 & $-1.498^{* * *}$ \\
& $(1.376)$ & $(-3.432)$ \\
Observations & 1,473 & 1,473 \\
Adjusted R2 & 0.90 & 0.34 \\
\hline
\end{tabular}

